\title{
Particle-Seawater Interaction of Neodymium in the North Atlantic
}

\author{
Torben Stichel,* Sven Kretschmer, Walter Geibert, Myriam Lambelet, Yves Plancherel, \\ Michiel Rutgers van der Loeff, and Tina van de Flierdt
}

Cite This: https://dx.doi.org/10.1021/acsearthspacechem.0c00034

Read Online

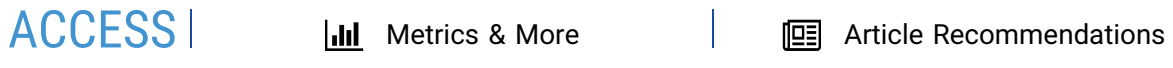

ABSTRACT: Dissolved neodymium (Nd) isotopes (expressed as $\varepsilon_{\mathrm{Nd}}$ ) have been widely used as a water mass tracer in paleoceanography. However, one aspect of the modern biogeochemical cycle of $\mathrm{Nd}$ that has been sparsely investigated is the interplay between dissolved and particulate phases in seawater. We here present the first regional data set on particulate $\mathrm{Nd}$ isotope compositions $\left(\varepsilon_{\mathrm{Nd}}^{\mathrm{p}}\right)$ and concentrations $\left([\mathrm{Nd}]_{\mathrm{p}}\right)$ from five stations in the western North Atlantic Ocean along the GEOTRACES GA02 transect, in conjunction with previously published dissolved $\mathrm{Nd}$ isotope compositions $\left(\varepsilon_{\mathrm{Nd}}{ }^{\mathrm{d}}\right)$ and concentrations $\left([\mathrm{Nd}]_{\mathrm{d}}\right)^{1}$. Key observations and interpretations from our new particulate data set include the following: (1) Low fractional contributions of $[\mathrm{Nd}]_{\mathrm{p}}$ to the total $\mathrm{Nd}$ inventory per volume unit of seawater ( $5 \%)$, with significant increases of up to $45 \%$ in benthic boundary layers. (2) Increasing $\mathrm{Nd}$ concentrations in suspended particulate matter $\left([\mathrm{Nd}]_{\mathrm{SPM}}\right)$ and fractions of lithogenic material with water depth, suggesting the

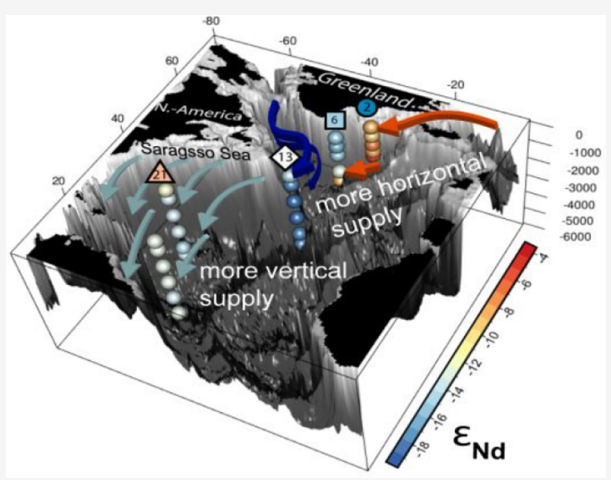
removal of $\mathrm{Nd}$ poor phases. (3) Different provenances of particulates in the subpolar and subtropical gyres as evidenced by their $\mathrm{Nd}$ isotope fingerprints reaching from $\varepsilon_{\mathrm{Nd}}{ }^{\mathrm{p}} \approx-20$ near the Labrador Basin (old continental crust), over $\varepsilon_{\mathrm{Nd}}{ }^{\mathrm{p}} \approx-4$ between Iceland and Greenland (young mafic provenance), to values of $\varepsilon_{\mathrm{Nd}} \mathrm{p}^{\mathrm{p}} \approx-13$ in the subtropics (similar to African dust signal). (4) Vertical heterogeneity of $\varepsilon_{\mathrm{Nd}} \mathrm{p}$ as well as large deviations from ambient seawater values in the subpolar gyre indicate advection of lithogenic particles in this area. (5) Vertically homogeneous $\varepsilon_{\mathrm{Nd}}^{\mathrm{p}}$ values in the subtropical gyre, indistinguishable from $\varepsilon_{\mathrm{Nd}}{ }^{\mathrm{d}}$ values, are indicative of predominance of vertical particulate supply. The process of reversible scavenging only seems to influence particulate signatures below $3 \mathrm{~km}$. Overall, we do not find evidence on enhanced particle dissolution, often invoked to explain the observed increase in dissolved $\mathrm{Nd}$ in the North Atlantic.

KEYWORDS: isotopes, trace-metals, lithogenic, marine, GEOTRACES, Pelagia, GA02

\section{INTRODUCTION}

The neodymium $(\mathrm{Nd})$ isotope composition of seawater (expressed as $\varepsilon_{\mathrm{Nd}}=\left\{\left({ }^{143} \mathrm{Nd} /{ }^{144} \mathrm{Nd}\right) /\right.$ CHUR -1$\} \times 10000$, with $\mathrm{CHUR}=0.512638)^{2}$ is a useful tracer of water mass provenance $^{3-6}$ and is frequently used to reconstruct past water mass configurations and in constraining the ocean's role in climate change on glacial-interglacial ${ }^{7-11}$ and Cenozoic time scales. $^{12-14}$ Regarding the modern underpinning of such palaeo studies, a large increase in observational data for dissolved $\mathrm{Nd}$ isotopes, $\mathrm{Nd}$ concentrations, and other rare earth element concentrations, as well as improved model parametrization, ${ }^{15-18}$ have led to a better understanding of input mechanisms and internal cycling of dissolved $\mathrm{Nd}$ concentrations and isotopes over recent years (e.g., refs 16, 19-23).

One of the key questions remaining for the modern biogeochemical cycle of dissolved $\mathrm{Nd}$ isotopes and concentrations is their decoupling in large parts of the global ocean. This observed decoupling was coined as the "Nd-paradox" by Lacan and Jeandel, ${ }^{24}$ following on from the pioneering work of Bertram and Elderfield. ${ }^{25}$ Goldstein and Hemming ${ }^{26}$ concluded that the observation that $\mathrm{Nd}$ isotope ratios laterally trace water masses (at least in the western Atlantic Ocean) appears to preclude strong vertical fluxes of $\mathrm{Nd}$ in the water column as explanation for increasing vertical enrichment in $\mathrm{Nd}$ concentrations. An aspect that was not considered in depth in this analysis was the interplay of particulate and dissolved $\mathrm{Nd}$ in the ocean. In fact, only a handful of studies have been conducted on modern particulate $\mathrm{Nd}$ isotopes and concentration. ${ }^{27-30}$ Such paired particulate-dissolved approaches are however what is required to fully address the $\mathrm{Nd}$-paradox.

The first coupled investigation of particulate and dissolved $\mathrm{Nd}$ isotope compositions by Jeandel et al. ${ }^{27}$ showed that dissolved $\mathrm{Nd}$ is transported to the deep ocean at deep water formation sites such as the North Atlantic and that the increase in concentrations with depth could be explained by a combination of vertical and horizontal supply. Siddall et al. ${ }^{16}$

Special Issue: Marine Particle Chemistry: Influence on Biogeochemical Cycles and Particle Export

Received: January 31, 2020

Revised: July 4, 2020

Accepted: July 14, 2020

Published: July 14, 2020 
were the first to numerically address this problem using a transport matrix model and concluded that the observed dissolved $\mathrm{Nd}$ distribution in the global ocean could be the result of combined lateral transport and reversible scavenging, reinforcing the important role of marine particles. However, the sparsely available dissolved and particulate $\mathrm{Nd}$ data at the time did not allow to provide information on realistic $K_{\mathrm{D}}$ 's (i.e., partition coefficients of particulate and dissolved $\mathrm{Nd}$ ) to further investigate the $\mathrm{Nd}$ paradox.

We here present the first regional data set of combined $\mathrm{Nd}$ isotope compositions and concentrations in seawater and marine particulates from the western North Atlantic in order to investigate the role of particulates in the marine biogeochemical cycle of Nd. Samples were collected along the same GEOTRACES transect (GA02, legs 1 and 2), and dissolved results were previously published by Lambelet et al. ${ }^{1}$ Adding new results on particulates for this important area of the global ocean enables a more in-depth evaluation on the provenance of particles, their vertical vs later supply and settling rates, as well as dissolved-particulate exchange processes for $\mathrm{Nd}$, including direct estimates of $K_{\mathrm{D}}$ values that can be used for future models.

\section{BACKGROUND ON THE STUDY AREA}

Hydrography. The hydrography of the study area is summarized in Figure 1A. It comprises the North Atlantic subpolar gyre in the Irminger and Labrador Basin and the subtropical gyre in the Sargasso Sea and the tropical Western Atlantic Ocean. The region is a key area for ocean circulation: North Atlantic Deep Water (NADW) is formed in the subpolar gyre and is constituted by Upper and Classical Labrador Seawater (ULSW, CLSW) from the Labrador Basin and overflow waters from the Northeastern Atlantic Ocean. ${ }^{31,32}$ Denmark Strait Overflow Water (DSOW) and Iceland Scotland Overflow Water (ISOW) mix within the Irminger Basin. ${ }^{33}$ The mixture of the deep parts of LSW and the overflow waters is what forms Irminger Sea water, often referred to as Lower NADW, ${ }^{34}$ whereas Upper NADW consists largely of ULSW and CLSW. ${ }^{35}$ The resulting NADW flows southward along the western margin of the Atlantic Ocean to form the Deep Western Boundary Current, (e.g., ref 36). This deep southward current is accompanied by the counter flow of the Gulf Stream (GS) at the surface and Southern Ocean waters at the bottom. ${ }^{31,37}$

Geology. Continental landmasses surrounding the North Atlantic comprise a large range of lithologies and ages (Figure 1B). Archaean rocks are exposed along the coast of Labrador Sea and in Southwest Greenland. The North Atlantic Craton is mostly Meso- to Neoarchaean in age (3200 to $2600 \mathrm{Ma}$, Figure 1B). The southern tip of Greenland, on the other hand, is characterized by the younger Ketilidian Orogen, with Paleoproterozoic $(\sim 1950 \mathrm{Ma})$ sedimentary rocks and basalts. North of the North Atlantic Craton, norites, tonalites, and various granites of Paleoproterozoic age constitute the Rae Craton forming Baffin Island and parts of Western Greenland. ${ }^{38,39}$ All these lithological units are among the oldest rocks worldwide and are characterized very negative $\varepsilon_{\mathrm{Nd}}$ values (Figure 1B, references in the caption). In contrast, young Paleogene and Holocene basalts, characterized by less negative and even positive $\varepsilon_{\mathrm{Nd}}$ values, are exposed at the continental shelf in East Greenland between $63^{\circ} \mathrm{N}$ and $70^{\circ} \mathrm{N}$ and in Iceland (Figure 1B). Southward from Newfoundland, on the western side of the North Atlantic, the exposed geology is
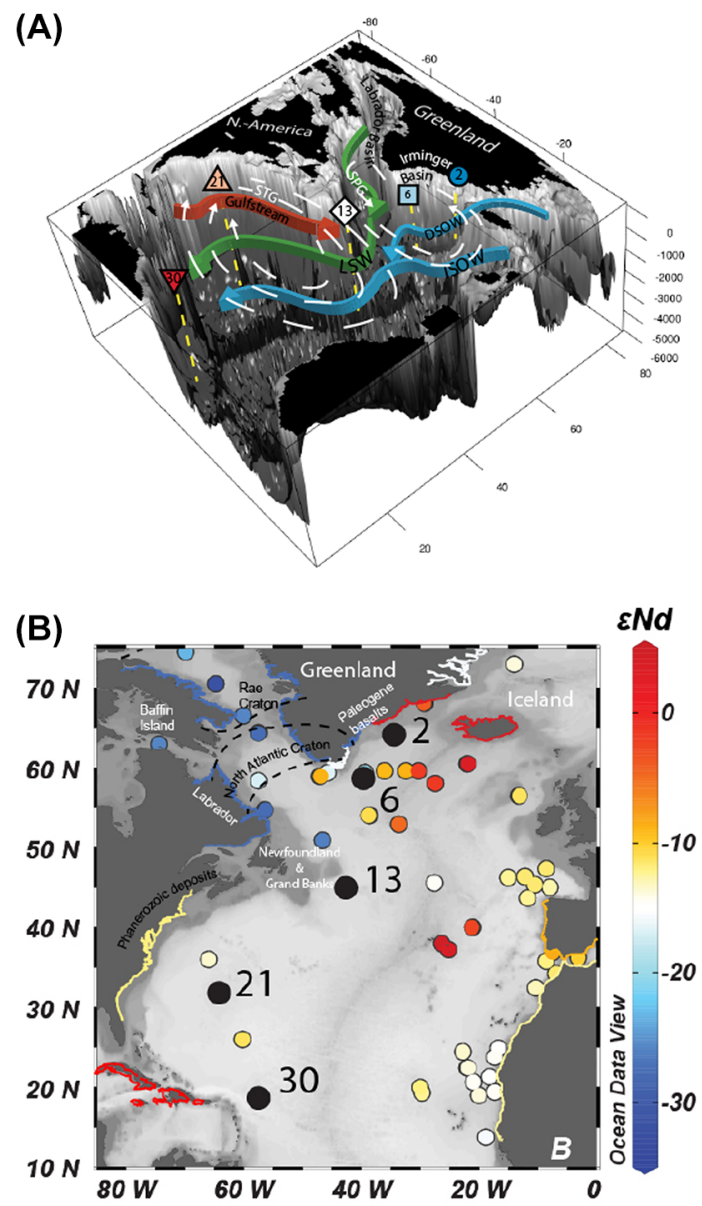

Figure 1. Maps of sample locations, oceanography and geology. (A) Map showing the sample location including the schematic flow paths of Denmark Strait Overflow Water (DSOW) and Island Scotland Overflow Water (ISOW) in blue, Labrador Sea Water (LSW) in green, and Gulfstream in red from refs 31-37. Station symbols are carried throughout the paper. (B) Neodymium isotope composition of bulk surface sediments (colored circles) of Holocene age and coast lines. Data from refs $21,27,82,53,54,66$, and 77-81. Map created using Ocean Data View $\left(\mathrm{ODV}^{83}\right)$.

composed largely of Phanerozoic (<550Ma) metamorphic, plutonic, and sedimentary rocks. This continental geology is largely reflected in intermediate $\varepsilon_{\mathrm{Nd}}$ values $(\sim-10)$ of Holocene aged marine core-top sediments in proximity to coastlines (Figure 1B).

\section{METHODS}

Sample Collection. Particulate samples were collected using volume-controlled in situ pumps (challenger Oceanic) during the northern two legs of the Dutch GEOTRACES section GA02 in May to June 2010 (leg 1: 64PE319; leg 2: 64PE321) at five to six depths of the water column at five stations (Figure 1A). In detail, the pumps were deployed at each station in an array of five pumps each using a timer to trigger the pumping at the target depth. Between 300 and 650 $\mathrm{L}$ of seawater was pumped for $2.5 \mathrm{~h}$ through a filter head containing one Supor filter (PALL, poly(ether sulfone) membrane, $142 \mathrm{~mm}$ diameter $\times 0.8 \mu \mathrm{m}$ pore size). At one occasion, a broken filter led to a very large filtered and unrealistic volume of $1250 \mathrm{~L}$ (station $6,2500 \mathrm{~m}$ ). At another occasion, a malfunctioning pump led to a very small filtered 
volume of approximately $5 \mathrm{~L}$ (station $21,3000 \mathrm{~m}$ ). The deepest samples were collected as close to the seafloor as possible to sample potential nepheloid layers. All filters were cleaned prior to the expedition by soaking in $10 \% \mathrm{HCl}(\mathrm{v} / \mathrm{v}$, double distilled) for $24 \mathrm{~h}$ and subsequently rinsed six times with Milli-Q water $(18.2 \mathrm{M} \Omega \mathrm{cm})$ on board. After recovery, the filter heads were dismounted from the pumps and the Supor filters were removed from the filter head under a laminar flow. From each filter, four subsamples were cut: Three $23 \mathrm{~mm}$ diameter subsamples were punched out from $1 / 6$ of the filter, corresponding to $3 \%$ of the filtered volume. These three subsamples were used for determining ${ }^{234} \mathrm{Th}$ activity (not reported here) and opal concentration on board. Biogenic opal (BSi) concentrations were measured spectrophotometrically. The remaining 5/6 of the filter was kept for trace metal isotope and concentration analysis in the home laboratory. Filter samples were packed in sealed plastic bags and stored at $5{ }^{\circ} \mathrm{C}$.

Laboratory Procedures. Filter digestion was carried out at Alfred Wegener Institute, Helmholtz Centre for Polar and Marine Research, Bremerhaven, Germany (AWI). For each station, a filter blank was processed along with the samples and experienced the same treatment as a sample did. Weighed spikes of ${ }^{150} \mathrm{Nd},{ }^{229} \mathrm{Th},{ }^{233} \mathrm{~Pa}$, and ${ }^{236} \mathrm{U}$ and $5 \mathrm{~mL}$ of concentrated $\mathrm{HNO}_{3}$ (double distilled) were added to each filter in a $60 \mathrm{~mL}$ Savillex vial and digested following the procedure described in Anderson et al., ${ }^{40}$ which is summarized briefly below. Vials were kept closed and heated at $150{ }^{\circ} \mathrm{C}$ for at least $16 \mathrm{~h}$. After that $3 \mathrm{~mL}$ of $\mathrm{HClO}_{4}$ was added, and the open vials were heated to $200{ }^{\circ} \mathrm{C}$ and capped as soon as the acid started fuming. The $\mathrm{HClO}_{4}$ digestion step was repeated several times (2-4 times) until the solution was free of any filter material. Silicates in the samples were broken down at $200{ }^{\circ} \mathrm{C}$ using $300 \mu \mathrm{L}$ of concentrated HF (suprapur); this step was repeated three times. With residual $\mathrm{HClO}_{4}$ still present, 5 $\mathrm{mL}$ of concentrated $\mathrm{HNO}_{3}$ was added and likewise heated to $200{ }^{\circ} \mathrm{C}$ until about $0.5 \mathrm{~mL}$ of fuming $\mathrm{HClO}_{4}$ remained. The last digestion step involved adding $0.5 \mathrm{~mL}$ of concentrated $\mathrm{HNO}_{3}$ and diluting with $5 \mathrm{~mL}$ of Milli-Q water. The jars were capped and heated overnight at $100{ }^{\circ} \mathrm{C}$. After cooling, the samples were transferred into preweighed $50 \mathrm{~mL}$ centrifuge vials using about $20 \mathrm{~mL}$ of Milli-Q water. Samples $(\sim 25 \mathrm{~mL})$ and separated subsamples of $1 \mathrm{~mL}$ were weighed. The subsamples were transferred into $10 \mathrm{~mL}$ centrifuge tubes and directly analyzed for elemental composition using ICP-MS and ICP-OES (see following section). The remaining sample was subjected to further chemical treatment in preparation for isotope analysis. As there was still a significant amount of sample matrix present, about $5 \mathrm{mg}$ of iron $\left(\mathrm{FeCl}_{3}\right)$ solution was added, and the $\mathrm{pH}$ of the solution was raised to 8.5 in order to form Fe-hydroxide and coprecipitate trace metals. The precipitate was centrifuged, rinsed with Milli-Q water, and subsequently redissolved in $0.5 \mathrm{~mL} \mathrm{HCl}$.

A first chemical separation was achieved using the fourcolumn setup after Anderson and Fleer ${ }^{41}$ and Anderson et al.. ${ }^{40}$ Below we briefly summarize the four key separation steps, relevant for $\mathrm{Nd}, \mathrm{Pa}$, and $\mathrm{Th}$. Polypropylene columns were filled with $1 \mathrm{~mL}$ of anion exchange resin (BioRad AG1X8, 200-400 mesh). The resin was precleaned using rinses of $8 \mathrm{~N} \mathrm{HNO}_{3}$, Milli-Q water, and $8 \mathrm{~N} \mathrm{HCl}$. After conditioning the columns with $6 \mathrm{~mL}$ of concentrated $\mathrm{HCl}$, samples were loaded and $\mathrm{Th}-$ $\mathrm{Nd}$ fractions were collected with $7.5 \mathrm{~mL}$ of the same acid. Following that, $\mathrm{Pa}(6 \mathrm{~mL}$ of concentrated $\mathrm{HCl} / 0.13 \mathrm{~N} \mathrm{HF})$, $\mathrm{Pu}(12 \mathrm{~mL}$ of $6 \mathrm{~N} \mathrm{HCl} / 0.26 \mathrm{~N} \mathrm{HF})$, and $\mathrm{U}$ and $\mathrm{Fe}(18 \mathrm{~mL}$ of
$0.1 \mathrm{~N} \mathrm{HCl}$ ) were sequentially eluted and collected. The combined $\mathrm{Th}$ and $\mathrm{Nd}$ cuts from the first column were evaporated to dryness and taken up in $1 \mathrm{~mL}$ of $8 \mathrm{~N} \mathrm{HNO}_{3}$ and then loaded onto the same anion exchange column described above after cleaning the resin with $6 \mathrm{~mL}$ of $8 \mathrm{~N} \mathrm{HNO}_{3}$. Neodymium was collected with $6 \mathrm{~mL}$ of the same acid, and Th was eluted with $6.2 \mathrm{~mL}$ of concentrated $\mathrm{HCl}$.

The $\mathrm{Pa}$ fraction from the first column was dried down and repeatedly evaporated in concentrated $\mathrm{HCl}$ and $\mathrm{HNO}_{3}$ to ensure the removal of the remaining HF. Protactinium was subsequently purified using the same column after cleaning it with a $3 \mathrm{~mL}$ mixture of concentrated $\mathrm{HCl}$ and $0.13 \mathrm{~N} \mathrm{HF}$ and $2 \times 10 \mathrm{~mL}$ of Milli-Q water. The resin was conditioned with 4 $\mathrm{mL}$ of concentrated $\mathrm{HCl}$, samples were loaded in $1 \mathrm{~mL}$ of concentrated $\mathrm{HCl}$, and any remaining matrix was eluted with a further $6 \mathrm{~mL}$ of the same acid, before collecting Pa with a $6 \mathrm{~mL}$ mixture of concentrated $\mathrm{HCl}$ and $0.13 \mathrm{~N} \mathrm{HF}$.

The $\mathrm{Nd}$ fraction was further purified at Imperial College London, UK. All acids used from here on are once quartz distilled unless otherwise stated. To remove remaining organic compounds, all dried samples and blanks were treated with 800 $\mu \mathrm{L}$ of aqua regia $(600 \mu \mathrm{L}$ of concentrated $\mathrm{HCl}+200 \mu \mathrm{L}$ of concentrated $\mathrm{HNO}_{3}$ ) at $100{ }^{\circ} \mathrm{C}$ for $24 \mathrm{~h}$ and then converted to nitrate form in $2 \times 1 \mathrm{~mL}$ of $1 \mathrm{~N} \mathrm{HNO}_{3}$, of which the first milliliter was capped for a few hours to catch potential traces of sample material from the walls of the vial. All samples yielded clear solutions at this point.

Separation of $\mathrm{Nd}$ from the remaining sample matrix and other rare earth elements was achieved with polypropylene columns filled with $1.4 \mathrm{~mL}$ of cation exchange resin (AG50WX8, 200-400 mesh) and $0.32 \mathrm{~mL}$ of Eichron Ln- resin bed (20-50 $\mu \mathrm{m}$ bead size), respectively. The detailed steps are described by Crocket et al. ${ }^{42}$ and Struve et al. ${ }^{43}$

Major and Trace Element Analysis. Major elements ( $\mathrm{Ca}$, $\mathrm{Fe}, \mathrm{Na}$, and $\mathrm{P}$ ) were measured on an ICP-OES instrument (Thermo Scientific - IRIS Intrepid), and trace element (Mn, $\mathrm{Al}, \mathrm{Ti}$ ) analyses and $\mathrm{U}, \mathrm{Th}$, and $\mathrm{Pa}$ isotope compositions were carried out on a ThermoFisher ELEMENT2 ICP-MS apparatus in high- and low-resolution modes, respectively, at the AWI. An ApexQ by ESI instrument was used as the sample inlet system for the ICP-MS apparatus. Each sample measurement was bracketed by measurement of the acid blank and the mass bias for $\mathrm{U}, \mathrm{Th}$, and $\mathrm{Pa}$ isotope composition. The mass bias was determined by the analysis of a natural $\mathrm{U}$ standard solution ( $0.2 \mathrm{ppb} \mathrm{U})$ and then calculated based on the natural ${ }^{238} \mathrm{U} /{ }^{235} \mathrm{U}$ ratio of 137.88 . For ${ }^{230} \mathrm{Th},{ }^{231} \mathrm{~Pa}$, and ${ }^{233} \mathrm{~Pa}$, a tailing correction was applied and the ${ }^{232} \mathrm{Th}$-hydrid contribution was accounted for. Peak tails on masses 230 and 231 were calculated from the beam intensities measured on the half masses below 232 amu. Tailing corrections on ${ }^{230} \mathrm{Th}$ accounted for $2-14 \%$. As the column separation of $\mathrm{Pa}$ from $\mathrm{Th}$ was very efficient, the ${ }^{232} \mathrm{Th}$ abundance in the Pa fraction was low. Thus, tailing corrections on ${ }^{231} \mathrm{~Pa}$ accounted for $0.1-$ $0.7 \%$. To correct for the ${ }^{232}$ Th-hydrid that interferes with mass 233 , the ${ }^{233} \mathrm{~Pa} /{ }^{232} \mathrm{Th}$ ratio was measured in the sample solution as well as in ${ }^{232} \mathrm{Th}$ standard solutions (ranging from 0.05 to 0.2 $\mathrm{ppb})$. The ${ }^{232} \mathrm{Th}$ standard runs revealed a ${ }^{233} \mathrm{~Pa} /{ }^{232} \mathrm{Th}$ ratio of $4 \times 10^{-5}-5 \times 10^{-5}$ which was constant throughout the different ${ }^{232} \mathrm{Th}$ concentrations. The ${ }^{232} \mathrm{Th}$-hydrid corrections accounted for $0.01-0.3 \%$.

Procedural blanks were prepared during the expedition in that precleaned Supor filters were cut into subsamples on board but not exposed to filter heads or seawater. At the home 
Table 1. Sample Locations of Particulate Material ${ }^{a}$

\begin{tabular}{|c|c|c|c|c|c|c|c|c|c|c|c|c|c|}
\hline \multirow[b]{2}{*}{ cruise } & \multirow[b]{2}{*}{$\begin{array}{l}\text { station } \\
(\#)\end{array}$} & \multirow[b]{2}{*}{ cast $(\#)$} & \multirow[b]{2}{*}{$\begin{array}{l}\text { latitude } \\
(\text { deg N) }\end{array}$} & \multirow[b]{2}{*}{$\begin{array}{c}\text { longitude } \\
(\text { deg E) }\end{array}$} & \multirow[b]{2}{*}{$\begin{array}{l}\text { depth } \\
\text { (m) }\end{array}$} & \multirow[b]{2}{*}{$\begin{array}{l}\text { density } \\
\left(\mathrm{kg} / \mathrm{m}^{3}\right)\end{array}$} & \multirow[b]{2}{*}{$\begin{array}{l}\mathrm{V} \\
(L)\end{array}$} & \multirow[b]{2}{*}{ remarks } & \multirow[b]{2}{*}{$\varepsilon_{\mathrm{Nd}}^{\mathrm{p}}$} & \multirow[b]{2}{*}{ $\pm 2 \mathrm{SD}$} & \multicolumn{2}{|c|}{$[\mathrm{Nd}]_{\mathrm{p}}$} & \multirow[b]{2}{*}{$\begin{array}{c}\text { Nd in } \\
\text { sample (ng) }\end{array}$} \\
\hline & & & & & & & & & & & $\mathrm{pmol} / \mathrm{kg}$ & $\mathrm{ng} / \mathrm{L}$ & \\
\hline PE-319 & 2 & 5 & 64.001 & -34.250 & 556 & 1027.69 & 492 & & -6.75 & 0.26 & 0.63 & 0.089 & 43.72 \\
\hline PE-319 & 2 & 5 & 64.001 & -34.250 & 1038 & 1027.74 & 475 & & -7.76 & 0.26 & 0.56 & 0.079 & 37.34 \\
\hline PE-319 & 2 & 5 & 64.001 & -34.250 & 1520 & 1027.79 & 521 & & -5.73 & 0.26 & 1.11 & 0.155 & 81.08 \\
\hline PE-319 & 2 & 5 & 64.001 & -34.250 & 1906 & 1027.82 & 431 & & -7.45 & 0.26 & 1.00 & 0.141 & 60.79 \\
\hline PE-319 & 2 & 5 & 64.001 & -34.250 & 2193 & 1027.92 & 449 & $\Delta$-Bottom: $0 \mathrm{~m}$ & -3.55 & 0.26 & 5.61 & 0.787 & 353.2 \\
\hline PE-319 & 2 & $\begin{array}{l}\text { filter } \\
\text { blank }\end{array}$ & & & & & & & -14.69 & 4.39 & & & 0.138 \\
\hline PE-319 & 6 & 3 & 58.602 & -39.705 & 611 & 1027.71 & 261 & $\begin{array}{l}\text { volume } \\
\text { uncertain }\end{array}$ & -14.88 & 0.17 & 0.32 & 0.045 & 11.84 \\
\hline PE-319 & 6 & 3 & 58.602 & -39.705 & 1093 & 1027.73 & 515 & $\begin{array}{l}\text { volume } \\
\text { uncertain }\end{array}$ & -16.18 & 0.17 & 0.35 & 0.050 & 25.55 \\
\hline PE-319 & 6 & 3 & 58.602 & -39.705 & 1575 & 1027.77 & 531 & & -15.07 & 0.17 & 0.44 & 0.062 & 32.88 \\
\hline PE-319 & 6 & 3 & 58.602 & -39.705 & 2539 & 1027.85 & & $\begin{array}{l}\text { volume } \\
\text { uncertain }\end{array}$ & -11.80 & 0.17 & & & 22.48 \\
\hline PE-319 & 6 & 3 & 58.602 & -39.705 & 3079 & 1027.93 & 305 & $\begin{array}{l}\Delta \text {-Bottom: } 30 \\
\mathrm{~m}\end{array}$ & -7.10 & 0.27 & 3.61 & 0.507 & 154.5 \\
\hline PE-319 & 6 & $\begin{array}{l}\text { filter } \\
\text { blank }\end{array}$ & & & & & & & -12.15 & 1.04 & & & 0.186 \\
\hline PE-319 & 13 & 3 & 44.845 & -42.550 & 548 & 1027.30 & 427 & & -14.47 & 0.48 & 0.89 & 0.124 & 53.11 \\
\hline PE-319 & 13 & 3 & 44.845 & -42.550 & 1042 & 1027.69 & 542 & & -18.09 & 0.17 & 0.88 & 0.124 & 67.06 \\
\hline PE-319 & 13 & 3 & 44.845 & -42.550 & 2031 & 1027.78 & 496 & & -19.74 & 0.17 & 0.87 & 0.122 & 60.49 \\
\hline PE-319 & 13 & 3 & 44.845 & -42.550 & 3019 & 1027.85 & 559 & & -19.03 & 0.17 & 0.77 & 0.108 & 60.10 \\
\hline PE-319 & 13 & 3 & 44.845 & -42.550 & 4007 & 1027.89 & 588 & & -18.17 & 0.17 & 1.39 & 0.196 & 115.1 \\
\hline PE-319 & 13 & 3 & 44.845 & -42.550 & 4678 & 1027.90 & 380 & $\begin{array}{l}\Delta \text {-Bottom: } 78 \\
\mathrm{~m}\end{array}$ & -17.95 & 0.27 & 18.4 & 2.576 & 978.6 \\
\hline PE-321 & 21 & 4 & 31.666 & -64.167 & 575 & 1026.62 & 638 & & -11.60 & 0.26 & 0.50 & 0.070 & 44.76 \\
\hline PE-321 & 21 & 4 & 31.666 & -64.167 & 1075 & 1027.62 & 527 & & -13.22 & 0.26 & 0.71 & 0.100 & 52.80 \\
\hline PE-321 & 21 & 4 & 31.666 & -64.167 & 2076 & 1027.81 & 502 & & -13.72 & 0.26 & 0.65 & 0.092 & 45.97 \\
\hline PE-321 & 21 & 4 & 31.666 & -64.167 & 3076 & 1027.88 & 5 & $\begin{array}{l}\text { no pumping, "dip } \\
\text { blank" }^{\prime \prime}\end{array}$ & -12.90 & 0.94 & & & 2.184 \\
\hline PE-321 & 21 & 4 & 31.666 & -64.167 & 4076 & 1027.89 & 539 & & -14.04 & 0.26 & 3.23 & 0.453 & 244.1 \\
\hline PE-321 & 21 & 4 & 31.666 & -64.167 & 4491 & 1027.90 & 318 & $\begin{array}{l}\Delta \text {-Bottom: } 46 \\
\mathrm{~m}\end{array}$ & -13.68 & 0.26 & 7.09 & 0.995 & 316.6 \\
\hline PE-321 & 21 & $\begin{array}{l}\text { filter } \\
\text { blank }\end{array}$ & & & & & & & -23.70 & 2.17 & & & 0.143 \\
\hline PE-321 & 30 & 4 & 18.572 & -57.612 & 512 & 1026.99 & 651 & & -12.21 & 0.27 & 0.85 & 0.120 & 78.09 \\
\hline PE-321 & 30 & 4 & 18.572 & -57.612 & 1011 & 1027.53 & 562 & & -11.98 & 0.27 & 1.01 & 0.142 & 79.87 \\
\hline PE-321 & 30 & 4 & 18.572 & -57.612 & 2008 & 1027.83 & 538 & & -12.49 & 0.26 & 0.61 & 0.085 & 45.71 \\
\hline PE-321 & 30 & 4 & 18.572 & -57.612 & 3005 & 1027.88 & 485 & & -12.66 & 0.26 & 0.58 & 0.082 & 39.59 \\
\hline PE-321 & 30 & 4 & 18.572 & -57.612 & 4002 & 1027.89 & 491 & & -12.85 & 0.26 & 0.49 & 0.069 & 33.78 \\
\hline PE-321 & 30 & 4 & 18.572 & -57.612 & 5038 & 1027.88 & 521 & $\begin{array}{l}\Delta \text {-Bottom: } 62 \\
\mathrm{~m}\end{array}$ & -12.14 & 0.27 & 1.16 & 0.163 & 85.09 \\
\hline PE-321 & 30 & $\begin{array}{l}\text { filter } \\
\text { blank }\end{array}$ & & & & & & & -13.28 & 1.02 & & & 0.218 \\
\hline PE-321 & 30 & $\begin{array}{l}\text { spike } \\
\text { blank }\end{array}$ & & & & & & & -6.42 & 5.06 & & & 0.051 \\
\hline
\end{tabular}

${ }^{a}$ Filtered volume (V) derived from the pumps' flow controller. Neodymium isotope composition expressed as $\varepsilon_{\mathrm{Nd}}=\left\{\left({ }^{143} \mathrm{Nd} /{ }^{144} \mathrm{Nd}\right) / \mathrm{CHUR}-1\right\}$ $\times 10000$, with CHUR $=0.512638){ }^{2}$ reported are 2 standard deviations as external error. Concentration of particulate $\mathrm{Nd}$ is derived by isotope dilution using a known amount of enriched ${ }^{150} \mathrm{Nd}$ spike.

laboratory, one procedural blank was analyzed for each batch of samples (10-12 samples). The procedural blank amount of ${ }^{230} \mathrm{Th}$ and ${ }^{232} \mathrm{Th}$ accounted for $0.2-11 \%$ and $0.02-2 \%$, respectively.

Neodymium (Nd) Isotope Composition and Concentration. Column-processed $\mathrm{Nd}$ samples were loaded on previously cleaned and degassed tungsten ribbon $(0.51 \mathrm{~mm}$ wide and $0.025 \mathrm{~mm}$ thick) for analysis as $\mathrm{NdO}^{+}$on a Thermo Triton 1 instrument equipped with 7 Faraday collector cups and a digital pyrometer following the procedures described by Crocket et al., ${ }^{42}$ Lambelet et al., ${ }^{1}$ and Struve et al. ${ }^{43}$ For each turret, on average, five JNdi-1 standard loads (5 ng each) were analyzed, yielding a mean ${ }^{143} \mathrm{Nd} /{ }^{144} \mathrm{Nd}=0.512096 \pm 14(2 \sigma, n$ $=21$ ). Sample results were subsequently corrected for the offset of the measured JNdi-1 ${ }^{143} \mathrm{Nd} /{ }^{144} \mathrm{Nd}$ ratio from the published ratio. ${ }^{44}$ A BCR-2 USGS rock standard, processed and analyzed alongside the samples, yielded a ${ }^{143} \mathrm{Nd} /{ }^{144} \mathrm{Nd}$ ratio of $0.512637 \pm 0.000006$, in agreement with the recommended ratio of 0.512638 reported by Weis et al. ${ }^{45}$ Neodymium concentrations were obtained by isotope dilution from the previously added ${ }^{150} \mathrm{Nd}$-spike (see the Supporting Information for spike composition). Filter blanks were treated as normal samples; i.e., they were loaded and measured the same way as samples and standards and yielded between 138 

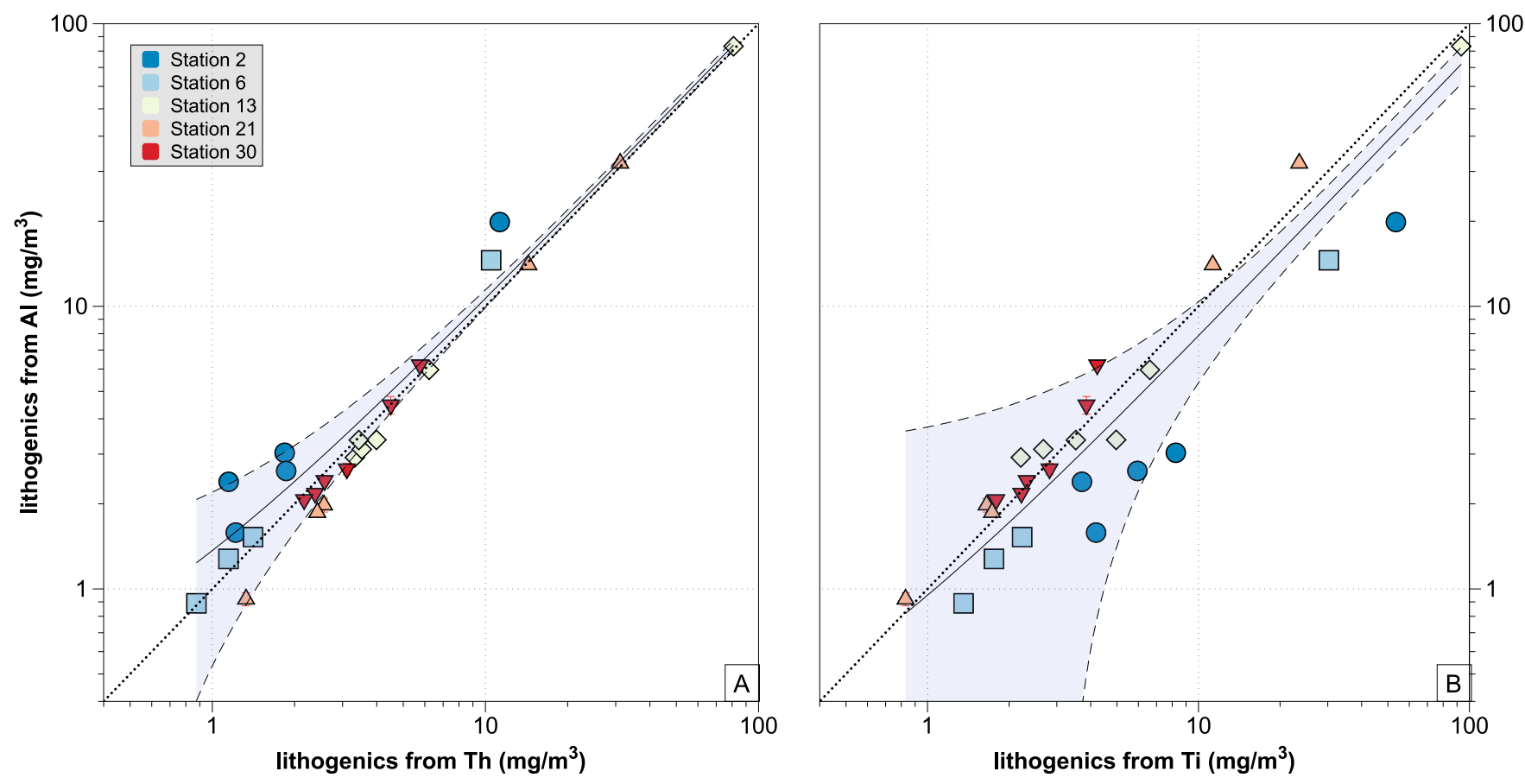

Figure 2. Comparison of different approaches to estimate the lithogenic concentration in marine particles along the GA02 transect. (A) Estimate based on normalizing the measured $\mathrm{Al}$ abundance in marine particles to that of the average upper continental crust (UCC) ${ }^{49}$ on the $y$-axis (our preferred estimate used throughout the paper) compared to the same approach utilizing ${ }^{232} \mathrm{Th}$. Bounds are set to $95 \%$ confidence. (B) Al-based estimate for the lithogenic concentration in marine particles as in (A), but now compared to a Ti-based approach on the $x$-axis. The correlation is characterized by a larger scatter than observed in panel (A). Bounds are set to $95 \%$ confidence.

and $218 \mathrm{pg}$ of $\mathrm{Nd}$, constituting less than $2 \%$ of the smallest sample size (11.84 ng, Table 1). Despite the low amount, it was possible to determine the $\mathrm{Nd}$ isotope composition of the blanks ranging from $\varepsilon_{\mathrm{Nd}}=-12.15 \pm 1.04$ to $-23.7 \pm 2.17(n=$ 4). Three of the four blanks had values similar to the samples, indicating a negligible influence on their isotope composition. Even the most extreme blank value of -23.7 would only shift the isotope composition of the smallest sample by $0.1 \varepsilon_{\mathrm{Nd}}$.

Suspended Particulate Matter (SPM) and Particle Composition. Total suspended particulate matter (SPM) was derived by summing up lithogenic and nonlithogenic components (geochemical approach). Although weighing of sample material on the filter (physical approach) would provide a more direct measure of filtered material, it also is associated with caveats and impracticalities: (i) each individual filter needs to be weight prior to the expedition, (ii) soluble salt precipitates need to be removed without removing any SPM, and (iii) drying of loaded filters can lead to an underestimation (losing material) or overestimation (contamination). The geochemical approach also provides a range of uncertainties, as it, for example, assumes the uniformity of individual geochemical compounds in SPM, such as fixed elemental and isotope ratios in the individual fractions that build up SPM. In detail, we determined SPM by summing the lithogenic fraction in the particles, $\mathrm{CaCO}_{3}$, biogenic $\mathrm{Si}(\mathrm{BSi})$, particulate organic matter (POM), iron hydroxides (Fe$\left.(\mathrm{OH})_{2}\right)$, and manganese oxides $\left(\mathrm{MnO}_{2}\right)$ :

$$
\begin{aligned}
{[\mathrm{SPM}]\left(\mathrm{mg} / \mathrm{m}^{3}\right)=} & {[\text { lithogenic }]+\left[\mathrm{CaCO}_{3}\right]+[\mathrm{BSi}] } \\
& +[\mathrm{POM}]+\left[\mathrm{Fe}(\mathrm{OH})_{2}\right]+\left[\mathrm{MnO}_{2}\right]
\end{aligned}
$$

The lithogenic part is estimated by assuming that $\mathrm{Al}$ in particles is predominantly of lithogenic origin, with a negligible contribution from the scavenging out of seawater. Aluminum also has the advantage that its concertation in crustal material is very homogeneous ${ }^{46,47}$ compared to $\mathrm{Th}$ or $\mathrm{Ti}$. Normalization to upper continental crust (UCC) estimates of $\mathrm{Al}$ concentration, $[\mathrm{Al}]_{\mathrm{UCC}}$, derives the mass of lithogenic particles per volume of seawater, $M_{\text {Lith. }}\left(\mathrm{mg} / \mathrm{m}^{3}\right)=[\mathrm{Al}]_{\mathrm{p}}\left(\mathrm{ng} / \mathrm{m}^{3}\right) /$ $[\mathrm{Al}]_{\mathrm{UCC}}(\mu \mathrm{g} / \mathrm{g})$. A typical value of 8.15 wt. $\%{ }^{46}$ was used for $[\mathrm{Al}]_{\mathrm{UCC}}$. Even though the lithologies of source rocks are subject to deviation from UCC, in particular for volcanic derived material originating from Iceland (http://georoc. mpch-mainz.gwdg.de/georoc/Csv Downloads/Ocean Island_Groups_comp/ICELAND.csv), we consider that this approach is suitable for the purpose of this study, as it is in good agreement with lithogenic particle fraction estimates based on other lithogenic tracers such as ${ }^{232} \mathrm{Th}$ and $\mathrm{Ti}$ (Figure 2). Calcium carbonate $\left(\mathrm{CaCO}_{3}\right)$ was estimated using calcium concentrations in particles, $[\mathrm{Ca}]_{\mathrm{p}}$, corrected for sea salt using sodium concentrations in particles, $[\mathrm{Na}]_{\mathrm{p}}$, with salt: $\mathrm{Na}$ of $3.586^{48}$ and $\mathrm{Ca}: \mathrm{Na}$ of $0.0382^{49}$ in sea salt. Intracellular Ca was estimated with a typical Ca:P of 0.767 (mass/mass). Intracellular and sea salt $\mathrm{Ca}$ was subtracted from measured $[\mathrm{Ca}]_{\mathrm{p}}$, and $\mathrm{CaCO}_{3}$ was calculated stoichiometrically by multiplying with $\mathrm{CaCO}_{3}: \mathrm{Ca}$ of 2.5 . Particulate organic matter (POM) was estimated by using particulate inorganic carbon (PIC) from $\mathrm{CaCO}_{3}$ and its relation to total particulate carbon in the North Atlantic oligotrophic gyre below $250 \mathrm{~m}$ (PIC/ $\mathrm{TPC}=0.19 \pm 0.1)^{50}$ to yield particulate organic carbon (POC). POM was subsequently derived by multiplying with a POM/POC weight ratio of $1.88 \mathrm{~g} / \mathrm{g} .{ }^{51}$ The remaining $\mathrm{Fe}(\mathrm{OH})_{2}$ and $\mathrm{MnO}_{2}$ were calculated by, respectively, subtracting $\mathrm{Fe}$ and $\mathrm{Mn}$ originating from UCC. It was pointed out in Lam et al. ${ }^{50}$ that, in contrast to $\mathrm{Al}, \mathrm{Fe}$ and $\mathrm{Mn}$ concentrations are variable due to different source composi- 

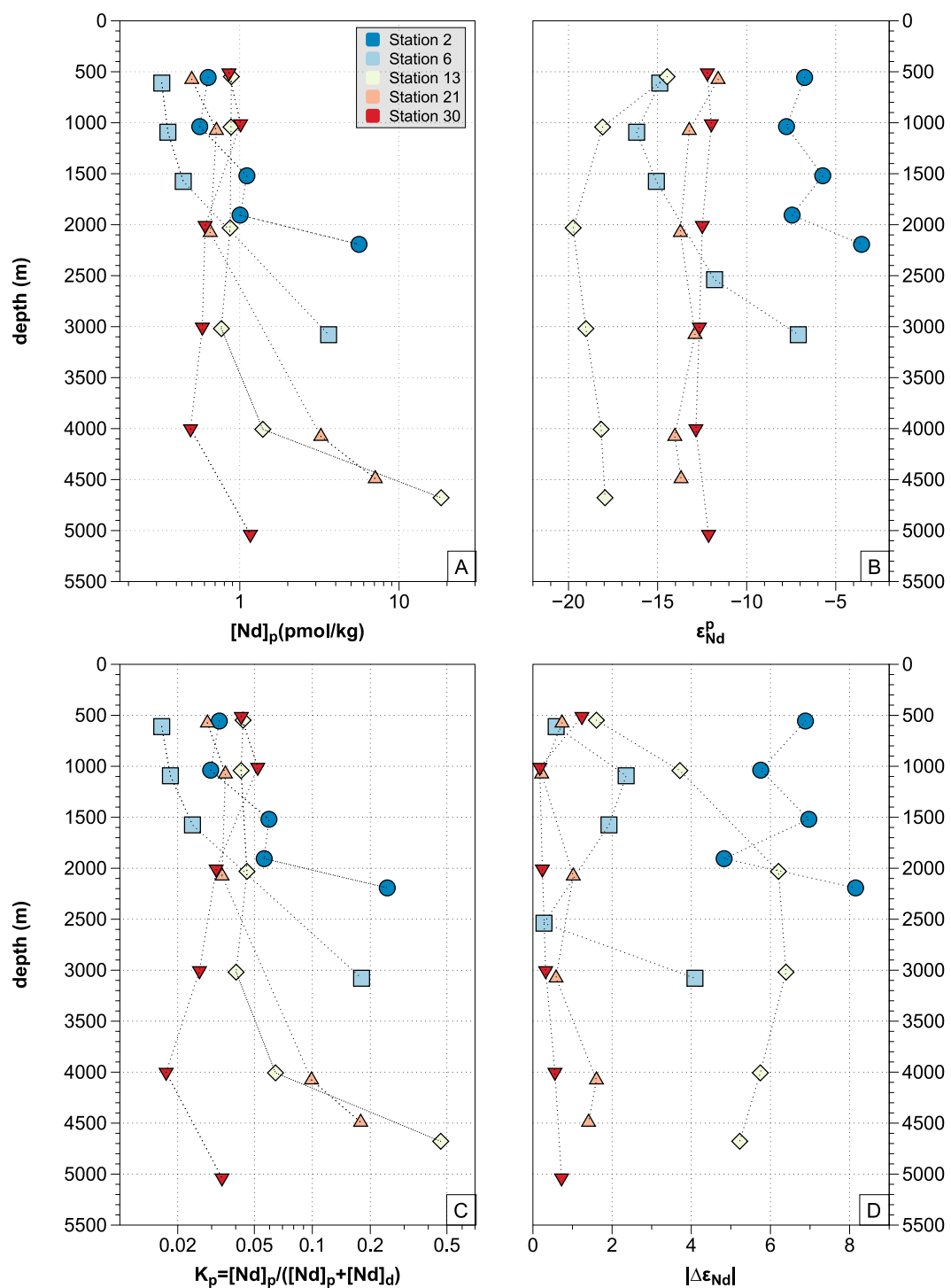

Figure 3. Results for $\mathrm{Nd}$ concentrations and isotope compositions in particulates and comparison with dissolved ones. (A) Vertical distribution of particulate $\mathrm{Nd},[\mathrm{Nd}]_{\mathrm{p}}$, per kilogram of seawater. (B) Vertical distribution of particulate $\mathrm{Nd}$ isotope composition $\left(\varepsilon_{\mathrm{Nd}}^{\mathrm{P}}\right)$. (C) Vertical distribution of the distribution coefficient between the particulate and dissolved $\mathrm{Nd}$ fraction: $K_{\mathrm{p}}=[\mathrm{Nd}]_{\mathrm{p}} /\left([\mathrm{Nd}]_{\mathrm{p}}+[\mathrm{Nd}]_{\mathrm{d}}\right)$. Dissolved values are interpolated from reported depths by Lambelet et al. ${ }^{1}$ (see text for further explanation). (D) Vertical distribution of the difference or offset $\left(\left|\Delta \varepsilon_{\mathrm{Nd}}\right|\right)$ of the Nd isotope composition from particles and seawater ${ }^{1}$ in absolute values to highlight only the differences between the dissolved and the particulate fraction by disregarding the sign.

tions and UCC values are thus not recommendable to derive a lithogenic Fe and Mn composition. Instead they used the less sensitive $\mathrm{Fe} / \mathrm{Ti}$ and $\mathrm{Mn} / \mathrm{Ti}$ ratios in UCC of 10 and 0.17 , respectively, to calculate the lithogenic fraction of these elements. In our study, we adapted this approach to determine $\mathrm{Fe}(\mathrm{OH})_{2}$ and $\mathrm{MnO}_{2}$ in particles. A summary of the components that were used for SPM calculation can be found in Table S-2 in the Supporting Information. Error propagation of the single fractions was used to estimate uncertainties of SPM.

Compared to Lam et al., 50 we find within an order of magnitude similar values for each component. There is, however, a larger discrepancy in $\mathrm{MnO}_{2}$ where our values are between 4 and 140 times higher. Even though these are large differences, these do not have a large influence on SPM, as $\mathrm{MnO}_{2}$ only contributes between 0 and $8 \%$ ( $1.4 \%$ on average). A detailed comparison can be found in the Supporting Information (Table S-3).

\section{RESULTS}

Major Particle Composition. Suspended PM varies significantly from $2.7 \pm 1$ to $183 \pm 6 \mathrm{mg} / \mathrm{m}^{3}$ (Table S-2). The highest values for SPM are found near the seafloor of each station except 30, where SPM is highest in the upper 500$1000 \mathrm{~m}$. For the remaining stations, SPM near the seafloor is found to be 3 to more than 10 times higher than the next shallower sample above. The single components show regional and local variations, which are briefly summarized here as they are not the main focus of this paper. The distribution of these components are shown in a bar plot in Figure S-2. Biogenic opal $(\mathrm{BSi})$ is more prominent in the upper water column down to $1500 \mathrm{~m}$ at stations 6 and 13 with $27 \%$ to almost $50 \%$ of the SPM, while the remaining samples are composed of $<20 \% \mathrm{BSi}$. The lithogenic fraction (referred to $\mathrm{F}_{\text {lith. }}$ in the plots) generally increases with water depth at all stations from $11 \%$ to over $76 \%$ with the highest values found below $4 \mathrm{~km}$ water depth in the 

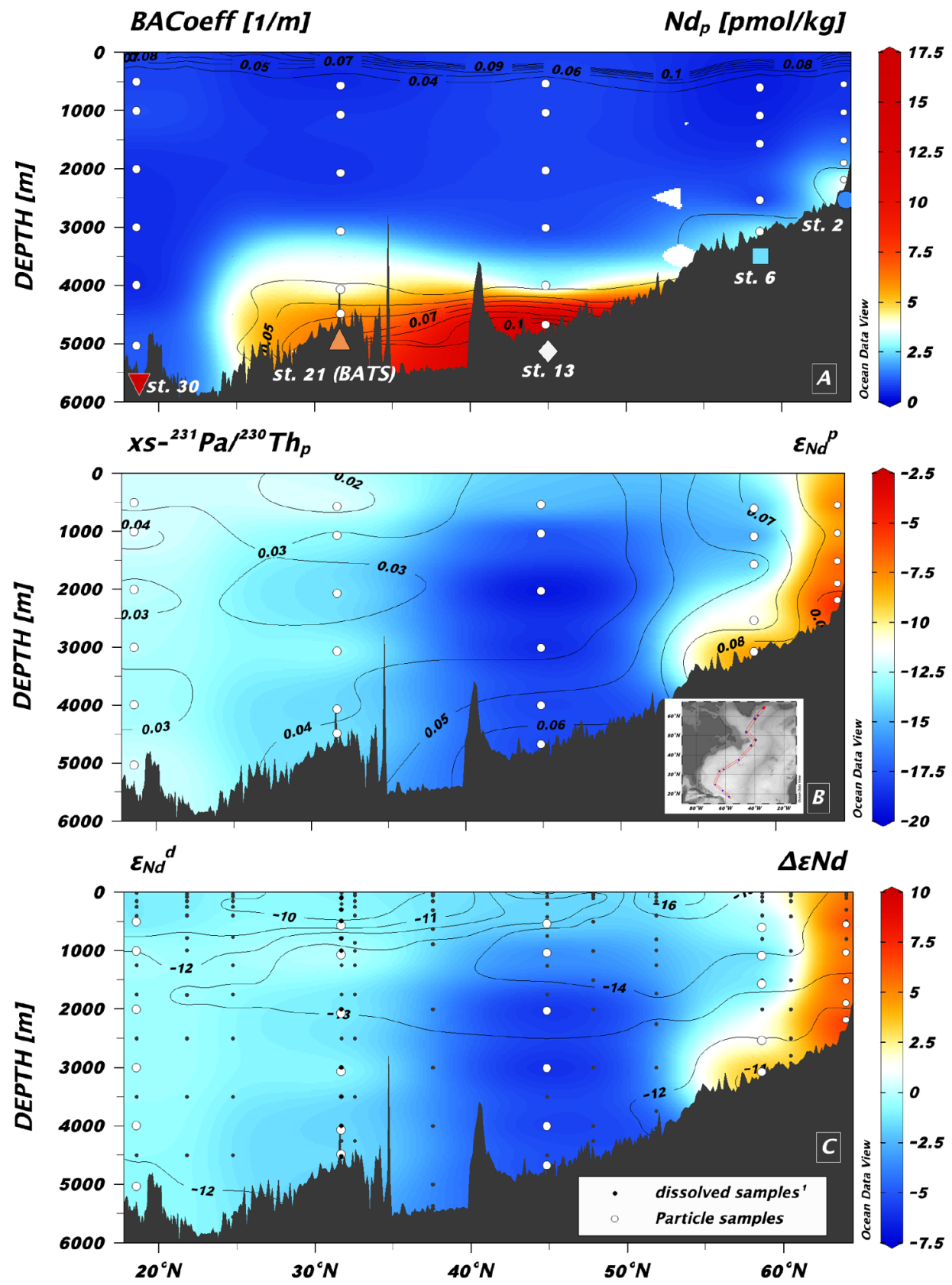

Figure 4. Beam attenuation, $\mathrm{Nd}$ isotope composition of particles, and difference between particulate and dissolved $\varepsilon_{\mathrm{Nd}}$ along the GA02 section. Sections along the transect of GA02 showing (A) particulate $\mathrm{Nd}\left([\mathrm{Nd}]_{\mathrm{p}}\right.$, nonlinear color) with beam attenuation as isolines and (B) $\mathrm{Nd}$ isotope composition $\left(\varepsilon_{\mathrm{Nd}}\right)$ of the particles in colors with the excess particulate ${ }^{231} \mathrm{~Pa} /{ }^{230} \mathrm{Th}$ in isolines. Section $(\mathrm{C})$ shows the difference between particles and the interpolated dissolved ${ }^{1}$ fraction $\left(\Delta \varepsilon_{\mathrm{Nd}}\right)$ in color with dissolved ${ }^{1} \varepsilon_{\mathrm{Nd}}{ }^{\mathrm{d}}$ in isolines. White circles and black dots represent particulate and dissolved samples, respectively. Section plots and map were created using ODV. ${ }^{83}$

subtropical gyre (stations 21 and 30). Calcium carbonate $\left(\mathrm{CaCO}_{3}\right)$ and particulate organic matter (POM) show similar values and variations from 17 to almost $69 \%$ and 12 to $41 \%$, respectively. These two fractions of SPM do not show large regional variations though with a tendency of higher values in the subpolar gyre and decrease with water depth. The components with the lowest fraction in SPM are $\mathrm{Fe}(\mathrm{OH})_{2}$ and $\mathrm{MnO}_{2}$ with maximum values of $3 \%$ and nearly $8 \%$, respectively. For the calculation of $\mathrm{Fe}(\mathrm{OH})_{2}$ (see Methods), the correction for lithogenic derived $\mathrm{Fe}$ often caused negative values for this fraction, which were set to "0." The highest values for $\mathrm{Fe}(\mathrm{OH})_{2}$ were found at station 2 at 556 and $1038 \mathrm{~m}$ with $\sim 3$ and $\sim 2 \%$, while most other samples showed values much lower than $1 \%$. For $\mathrm{MnO}_{2}$, the highest values were found in the deep subtropical gyre with values between 2 and nearly $8 \%$, while stations 2,6 , and 13 were on average only at $0.3 \%$.

Vertical and Spatial Distribution of Particulate $\mathrm{Nd}$ Concentrations. For comparison with the published dissolved $\mathrm{Nd}$ fraction, ${ }^{1}[\mathrm{Nd}]_{\mathrm{d}}$, we report the particulate concentration of $\mathrm{Nd},[\mathrm{Nd}]_{\mathrm{p}}$, in $\mathrm{pmol} / \mathrm{kg}$ of seawater (Table 1 , Figure 3). The volume to mass conversion was done by calculating the density of seawater from salinity, potential temperature, and pressure. It is noted that, despite the high resolution of the dissolved $\mathrm{Nd}$ profiles reported by Lambelet et 

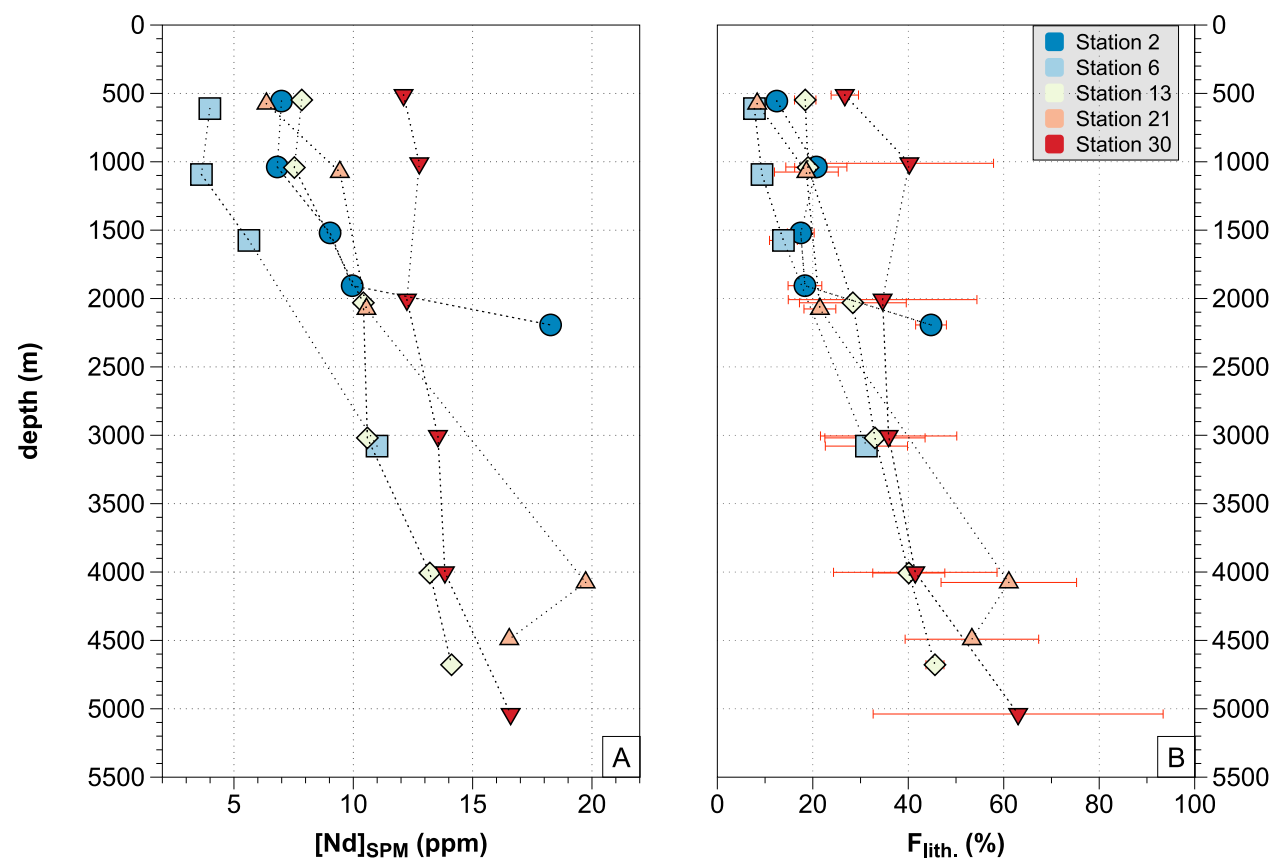

Figure 5. Neodymium concentration in suspended particulate matter and the fraction of lithogenic material in the same particulates. (A) Vertical distribution of the $\mathrm{Nd}$ in suspended particulate material $\left(\mathrm{Nd}_{\mathrm{SPM}}\right)$, obtained by normalizing $[\mathrm{Nd}]_{\mathrm{p}}$ to the concentration of suspended particulate matter (SPM). (B) Vertical distribution of the lithogenic fraction $\left(\mathrm{F}_{\text {lith }}\right)$ in suspended particulate matter.

al., ${ }^{1}$ exact depths of particulate sample collection did deviate from dissolved samples collected on a different cast on the same cruise. Missing seawater data points were derived by linear interpolation between known data points in order to be able to calculate $\mathrm{Nd}$ partition coefficients between suspended material and seawater (see the Supporting Information for details). Dissolved sample depths deviated by between 10 and $500 \mathrm{~m}$ from depths where the pumps were deployed.

Particulate Nd concentrations $\left([\mathrm{Nd}]_{\mathrm{p}}\right)$ range from 0.32 to $18.4 \mathrm{pmol} / \mathrm{kg}$, with the highest values reported for the particulate samples closest to the seafloor (Table 1, Figure $3 \mathrm{~A})$. In detail, the highest $[\mathrm{Nd}]_{\mathrm{p}}$ was found at the bottom of station 13 (Grand Banks) and the lowest $[\mathrm{Nd}]_{\mathrm{p}}$ for a sample close to the seafloor was observed at station $30(1.2 \mathrm{pmol} / \mathrm{kg})$, marking this station as the only station which does not show a benthic increase in $[\mathrm{Nd}]_{\mathrm{p}}$. Away from the seafloor, the average $[\mathrm{Nd}]_{\mathrm{p}}$ shows small variability with $0.85 \pm 0.6 \mathrm{pmol} / \mathrm{kg}$, compared to the benthic $[\mathrm{Nd}]_{\mathrm{p}}$ average of $7.17 \pm 6.6 \mathrm{pmol} / \mathrm{kg}$. The lowest values in the water column are found at station 6 $(0.32-3.61 \mathrm{pmol} / \mathrm{kg})$ in the subpolar gyre and in the upper $2000 \mathrm{~m}$ of station $21(0.5-0.7 \mathrm{pmol} / \mathrm{kg})$ in the subtropical gyre (Table 1, Figure 3A). Neglecting the samples taken near the seafloor, the distribution coefficient between the particulate and dissolved ${ }^{1}$ fractions $K_{\mathrm{p}}=[\mathrm{Nd}]_{\mathrm{p}} /\left([\mathrm{Nd}]_{\mathrm{p}}+[\mathrm{Nd}]_{\mathrm{d}}\right)$ was found to be smaller than 0.05 in the water column (Figure 3C). Generally, $K_{\mathrm{p}}$ increases near the bottom for all stations (stations 2-21) with the exception of station $30(5038 \mathrm{~m})$, where the bottom-most $K_{\mathrm{p}}$ of 0.03 , matches mid-depth values (Figure 3B). The high $[\mathrm{Nd}]_{\mathrm{p}}$ near the seafloor is in accordance with the presence of benthic nepheloid layers (BNL), as indicated by elevated beam attenuation (Figure 4A). In the BNL, $K_{\mathrm{p}}$ values are an order of magnitude higher (i.e., up to 0.45 ), indicating that nearly half of the total $\mathrm{Nd}$ concentration in a specific parcel of water is in the particulate phase, while in the overlying water column it is typically only a tenth of this value.
The Nd concentration in particles $\left([\mathrm{Nd}]_{\mathrm{SPM}}\right)$, obtained by normalizing $[\mathrm{Nd}]_{\mathrm{p}}$ to the concentration of suspended particulate matter (SPM, see Methods), $[\mathrm{Nd}]_{\mathrm{SPM}}=[\mathrm{Nd}]_{\mathrm{p}} /$ SPM, ranges from $4 \mathrm{ppm}$ (station $6,1093 \mathrm{~m}$ ) to $20 \mathrm{ppm}$ (station 21 at $4076 \mathrm{~m}$, Table 1), which is lower than the average upper continental crust (UCC) value of $27 \mathrm{ppm} .{ }^{46}$ The lowest values of $[\mathrm{Nd}]_{\mathrm{SPM}}$ are found in the shallowest part of each profile and show a steady increase with depth (Figure $5 A$ ). Single profile slopes range from $\sim 0.5$ and $\sim 4 \mathrm{ppm} / \mathrm{km}$, calculated using all measurements between $500 \mathrm{~m}$ (e.g., the shallowest depth collected) and the seafloor (Figure 5A). This rate increases by a factor 4-10 close to the seafloor for 4 of the 5 stations and is most pronounced at station $2(\sim 40 \mathrm{ppm} / \mathrm{km})$. A near bottom decrease in $[\mathrm{Nd}]_{\mathrm{SPM}}(-5.5 \mathrm{ppm} / \mathrm{km})$ is observed between the two deepest samples of station 21 near the Bermuda Atlantic Time Series (BATS). Overall, increasing $[\mathrm{Nd}]_{\mathrm{SPM}}$ is accompanied by an increase in the lithogenic fraction $\left(\mathrm{F}_{\text {lith }}=[\right.$ lithogenic $\left.] / \mathrm{SPM}\right)$ of particulate material (Figure $5 \mathrm{~B}$ ). This increase in $[\mathrm{Nd}]_{\mathrm{SPM}}$ and the relatively stable $[\mathrm{Nd}]_{\mathrm{p}}$ suggest accumulation of $\mathrm{Nd}$ in the particles either by dissolution of $\mathrm{Nd}$ poor phases such as $\mathrm{CaCO}_{3}$ with depth leaving behind (lithogenic) mineral phases with elevated $\mathrm{Nd}$ or by increased adsorption of seawater $\mathrm{Nd}$ onto these residual phases. Particles from the shallower samples are characterized by the lowest fraction of lithogenic material (Figure 5B). Geographically, the lowest fraction of lithogenic particles is found at stations in the subpolar gyre, with higher abundances of lithogenic material in the subtropical gyre.

Vertical and Spatial Distribution of Particulate Nd Isotope Composition. The $\mathrm{Nd}$ isotope composition of the bulk particles shows a large range from $\varepsilon_{\mathrm{Nd}}{ }^{\mathrm{p}}=-3.6$ at $2197 \mathrm{~m}$ of station 2 in the Irminger Basin to $\varepsilon_{\mathrm{Nd}}{ }^{\mathrm{p}}=-19.7$ at $2031 \mathrm{~m}$ at station 13 near the Grand Banks (Figure 3B, Table 1). The shallowest station 2 in the subpolar gyre shows radiogenic $\varepsilon_{\mathrm{Nd}}^{\mathrm{p}}$ values of as high as -3.5 at the seafloor and not exceeding -7.8 throughout the water column. Only the bottom-most 
Table 2. Derived Parameters Using Table 1 and Suspended Particulate Material (SPM, See Table S-2)

\begin{tabular}{|c|c|c|c|c|c|c|c|c|}
\hline \multirow[b]{2}{*}{$\begin{array}{l}\text { station } \\
(\#)\end{array}$} & \multirow[b]{2}{*}{$\begin{array}{l}\text { depth } \\
(\mathrm{m})\end{array}$} & \multirow[b]{2}{*}{$\underset{\left(\mathrm{mg} / \mathrm{m}^{3}\right)^{a}}{\mathrm{SPM}}$} & \multicolumn{2}{|c|}{ total $\mathrm{Nd}^{b}$} & \multirow[b]{2}{*}{$\begin{array}{l}{[\mathrm{Nd}]_{\mathrm{SpM}}} \\
(\mathrm{ppm})\end{array}$} & \multirow[b]{2}{*}{$\frac{K_{\mathrm{p}}([\mathrm{pNd}] /([\mathrm{dNd}]+}{[\mathrm{pNd}]))^{b}}$} & \multirow[b]{2}{*}{$K_{\mathrm{D}}\left(\left(\left([\mathrm{Nd}]_{\mathrm{p}} / \mathrm{SPM}\right) /\left[0^{9}\right)^{b} / \mathrm{Nd}\right]_{\mathrm{d}}\right) \times$} & \multirow[b]{2}{*}{$\begin{array}{c}\Delta \varepsilon_{\mathrm{Nd}}\left(\left(\varepsilon_{\mathrm{Nd}}^{\mathrm{p}}-\right.\right. \\
\left.\left.\varepsilon_{\mathrm{Nd}}\right)\right)^{d}\end{array}$} \\
\hline & & & $\mathrm{ng} / \mathrm{kg}$ & $\mathrm{pmol} / \mathrm{kg}$ & & & & \\
\hline 2 & 556 & 12.7 & 2.63 & 18.22 & 6.99 & 0.0329 & $2.75 \times 10^{6}$ & 6.88 \\
\hline 2 & 1038 & 11.5 & 2.58 & 17.89 & 6.81 & 0.0296 & $2.72 \times 10^{6}$ & 5.75 \\
\hline 2 & 1520 & 17.2 & 2.54 & 17.62 & 9.03 & 0.0595 & $3.78 \times 10^{6}$ & 6.97 \\
\hline 2 & 1906 & 14.2 & 2.44 & 16.89 & 9.95 & 0.0562 & $4.33 \times 10^{6}$ & 4.83 \\
\hline 2 & 2193 & 43.1 & 3.12 & 21.64 & 18.27 & 0.2451 & $7.75 \times 10^{6}$ & 8.15 \\
\hline 6 & 611 & 11.4 & 2.68 & 18.55 & 3.99 & 0.0165 & $1.60 \times 10^{6}$ & -0.59 \\
\hline 6 & 1093 & 13.6 & 2.64 & 18.27 & 3.64 & 0.0183 & $1.49 \times 10^{6}$ & -2.36 \\
\hline 6 & 1575 & 11.0 & 2.53 & 17.52 & 5.63 & 0.0239 & $2.41 \times 10^{6}$ & -1.92 \\
\hline 6 & 2539 & & & & & & & 0.28 \\
\hline 6 & 3079 & 46.1 & 2.81 & 19.50 & 10.99 & 0.1802 & $5.01 \times 10^{6}$ & 4.09 \\
\hline 13 & 548 & 15.9 & 2.77 & 19.19 & 7.84 & 0.0437 & $3.13 \times 10^{6}$ & -1.60 \\
\hline 13 & 1042 & 16.4 & 2.82 & 19.55 & 7.53 & 0.0427 & $2.95 \times 10^{6}$ & -3.71 \\
\hline 13 & 2031 & 11.7 & 2.67 & 18.49 & 10.42 & 0.0458 & $4.32 \times 10^{6}$ & -6.20 \\
\hline 13 & 3019 & 10.2 & 2.67 & 18.55 & 10.59 & 0.0402 & $4.35 \times 10^{6}$ & -6.39 \\
\hline 13 & 4007 & 14.8 & 3.04 & 21.08 & 13.21 & 0.0644 & $4.90 \times 10^{6}$ & -5.75 \\
\hline 13 & 4678 & 182.5 & 5.55 & 38.46 & 14.12 & 0.4644 & $4.90 \times 10^{6}$ & -5.22 \\
\hline 21 & 575 & 11.0 & 2.40 & 16.61 & 6.36 & 0.0285 & $2.88 \times 10^{6}$ & -0.74 \\
\hline 21 & 1075 & 10.6 & 2.76 & 19.11 & 9.44 & 0.0353 & $3.75 \times 10^{6}$ & 0.22 \\
\hline 21 & 2076 & 8.7 & 2.62 & 18.16 & 10.55 & 0.0340 & $4.40 \times 10^{6}$ & -1.02 \\
\hline 21 & 3076 & & & & & & & -0.58 \\
\hline 21 & 4076 & 23.0 & 4.45 & 30.85 & 19.73 & 0.0990 & $5.20 \times 10^{6}$ & -1.61 \\
\hline 21 & 4491 & 60.2 & 5.43 & 37.63 & 16.53 & 0.1783 & $3.92 \times 10^{6}$ & -1.41 \\
\hline 30 & 512 & 9.9 & 2.73 & 18.94 & 12.11 & 0.0428 & $4.88 \times 10^{6}$ & -1.24 \\
\hline 30 & 1011 & 11.1 & 2.66 & 18.41 & 12.77 & 0.0521 & $5.35 \times 10^{6}$ & -0.17 \\
\hline 30 & 2008 & 6.9 & 2.61 & 18.09 & 12.25 & 0.0317 & $5.12 \times 10^{6}$ & 0.24 \\
\hline 30 & 3005 & 6.0 & 3.06 & 21.23 & 13.55 & 0.0259 & $4.80 \times 10^{6}$ & -0.32 \\
\hline 30 & 4002 & 5.0 & 3.85 & 26.68 & 13.84 & 0.0174 & $3.87 \times 10^{6}$ & -0.56 \\
\hline 30 & 5038 & 9.9 & 4.68 & 32.47 & 16.59 & 0.0339 & $3.87 \times 10^{6}$ & -0.72 \\
\hline
\end{tabular}

${ }^{a}$ Sum of particulate $[$ lithogenic $]+[\mathrm{bSi}]+\left[\mathrm{CaCO}_{3}\right]+[\mathrm{POM}]+\left[\mathrm{Fe}(\mathrm{OH})_{2}\right]+\left[\mathrm{MnO}_{2}\right]\left(\mathrm{cf}\right.$. Table S-2). ${ }^{b}$ Using linearly interpolated dissolved values in Lambelet et al. ${ }^{1}$ (cf. Table S-3).

sample at station 6 has a similarly radiogenic value $\left(\varepsilon_{\mathrm{Nd}}^{\mathrm{p}}=\right.$ -7.1 at $3079 \mathrm{~m})$. Station 6 also has the largest vertical isotope gradient of any station measured in this study (Figure $3 \mathrm{~B} ; \varepsilon_{\mathrm{Nd}}{ }^{\mathrm{p}}$ $\sim-15$ above $1500 \mathrm{~m} ; \varepsilon_{\mathrm{Nd}}^{\mathrm{p}}=-7.1$ at the seafloor). Station 13 , just east of the Grand Banks, shows the least radiogenic $\mathrm{Nd}$ isotope values $\left(\varepsilon_{\mathrm{Nd}}^{\mathrm{p}}=-14.5\right.$ at $548 \mathrm{~m}$ to -17.9 at $\left.4678 \mathrm{~m}\right)$ and is the only station that possesses a clear mid-depth minimum with $\varepsilon_{\mathrm{Nd}}^{\mathrm{p}}=-19.7$ at $2031 \mathrm{~m}$. Station 21 (BATS) site and station 30 (east of West Indies) show no clear vertical structures, with near constant $\varepsilon_{\mathrm{Nd}}{ }^{\mathrm{p}}$ values with depth (-12 to -14; Figures 3B and 4B).

Comparing the dissolved $\mathrm{Nd}$ isotope composition $\left(\varepsilon_{\mathrm{Nd}}^{\mathrm{d}}\right)$ published by Lambelet et al. ${ }^{1}$ with our particulate $\varepsilon_{\mathrm{Nd}}{ }^{\mathrm{p}}$ data for the same stations, reveals a clear meridional gradient in isotope compositions between the two phases $\left(\Delta \varepsilon_{\mathrm{Nd}}=\varepsilon_{\mathrm{Nd}}^{\mathrm{p}}-\varepsilon_{\mathrm{Nd}}^{\mathrm{d}}\right.$; Figure $4 \mathrm{C}$; Table 2). Omitting the sign (i.e., disregarding whether the particulate phase shows a more or less radiogenic $\mathrm{Nd}$ isotope signal), the largest deviation in $\varepsilon_{\mathrm{Nd}}$ values between the two phases is observed in the northern part of the study area $\left(\Delta \varepsilon_{\mathrm{Nd}}^{\text {abs }}=\left|\Delta \varepsilon_{\mathrm{Nd}}\right|\right.$, stations 2, 6, and 13; Figure 3D). Rather similar isotope compositions are revealed in the southern part of the transect (Figure 3D). With the sign, $\Delta \varepsilon_{\mathrm{Nd}}$ is positive at station 2 east of Greenland as the dissolved fraction is less radiogenic (smaller $\varepsilon_{\mathrm{Nd}}$ ) than the particulate fraction by $4.8-8.1 \varepsilon_{\mathrm{Nd}}$ units (Figure 4C). About $2200 \mathrm{~km}$ further south at station 13 (Grand Banks), $\Delta \varepsilon_{\mathrm{Nd}}$ values become negative and the particulates' $\varepsilon_{\mathrm{Nd}}{ }^{\mathrm{p}}$ signal is up to 6.4
$\varepsilon_{\mathrm{Nd}}$ units lower than that of the dissolved $\mathrm{Nd}$ isotope composition of ambient seawater at $2000 \mathrm{~m}$ depth. Station 6, off the southern tip of Greenland, located between stations 2 and 13 , has intermediate particulate-to-dissolved offsets, with moderately negative $\Delta \varepsilon_{\mathrm{Nd}}$ between 1000 and $2000 \mathrm{~m}$ and a more pronounced positive $\Delta \varepsilon_{\mathrm{Nd}}=+4.1$ near the seafloor (Figure 4B). The observed offsets are dominated by the greater range of particulate $\varepsilon_{\mathrm{Nd}}{ }^{\mathrm{p}}$ compared to the range of dissolved $\varepsilon_{\mathrm{Nd}}$ values (Figure $3 \mathrm{~B}$ and $\mathrm{D}$ ). The smallest and within error negligible $\Delta \varepsilon_{\mathrm{Nd}}$ offsets are found further south at stations 21 and 30 , in agreement with results described previously for two water depths at BATS. ${ }^{30}$

\section{DISCUSSION}

Comparison with Previous Particle Measurements in the Sargasso Sea. Results for particulate $\mathrm{Nd}$ isotope compositions and concentrations for station 21 (BATS) can be compared with previous studies on marine particle $\mathrm{Nd}$ isotope composition and concentration in the Sargasso Sea, ${ }^{27}$ the GEOTRACES intercalibration exercise from 2008 (ref. $^{30}$ ) and the US GEOTRACES transect GA03, which collected particulate samples at BATS during their 2011 expedition (Lam et al., 2015; no $\mathrm{Nd}$ isotope data; $[\mathrm{Nd}]_{\mathrm{p}}$ data are available online at http://data.bco-dmo.org/jg/dir/BCO/ GEOTRACES/NorthAtlanticTransect/). Table S-3 summarizes our new data for the BATS station 21 and those previously published at very similar water depths. Lam et al. ${ }^{50}$ 

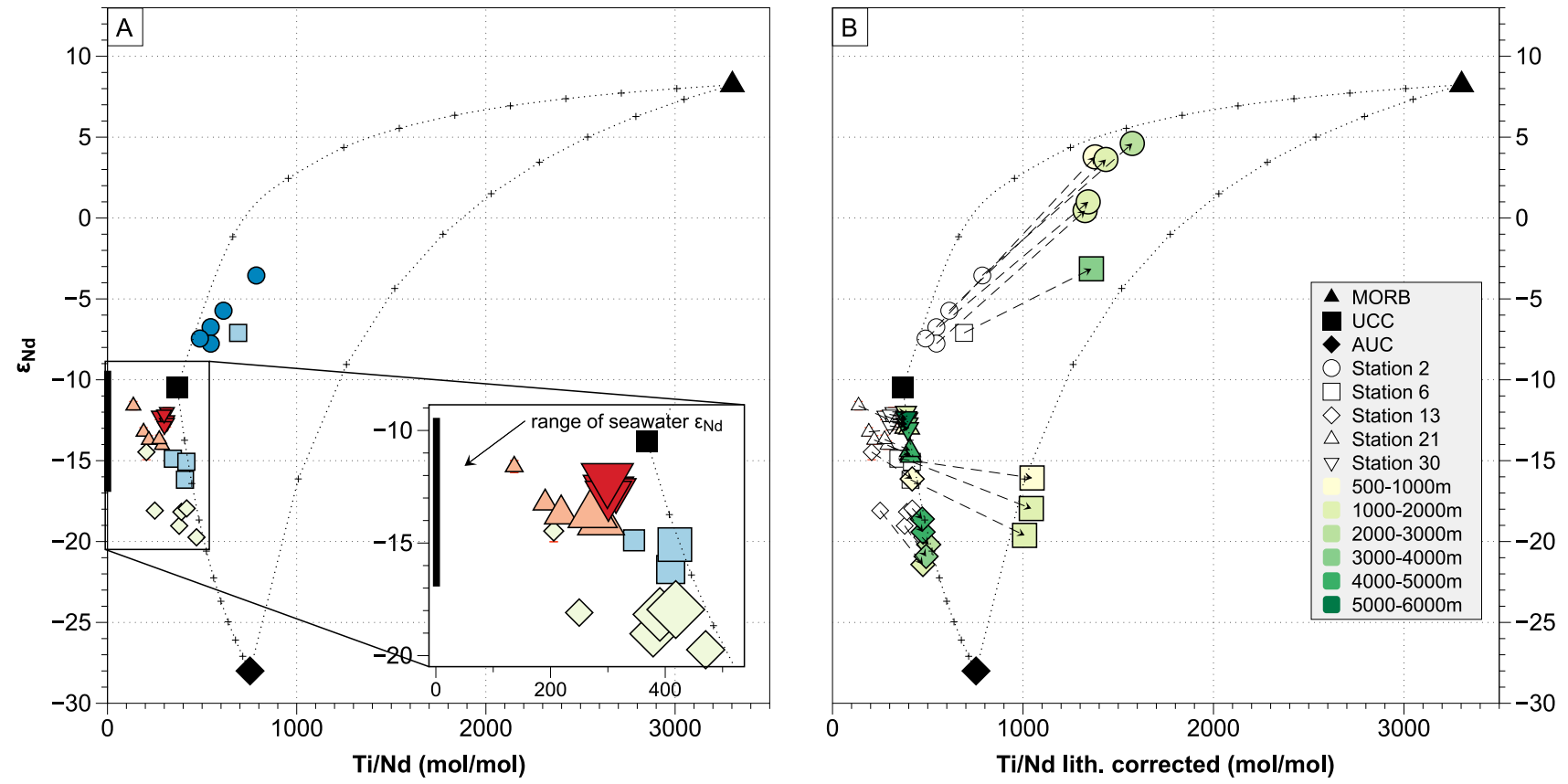

Figure 6. Relationship of marine particulate $\mathrm{Nd}$ isotope compositions and $\mathrm{Ti} / \mathrm{Nd}$ ratios along $\mathrm{GA02}$ relative various lithogenic source rocks. (A) Marine particle compositions (colored symbols) in the context of a lithogenic input mixing envelope with $10 \%$ increments defined by Mid-Ocean Ridge-Basalt (MORB, black triangle), ${ }^{63}$ Archaean Upper Crust (AUC, black diamond), ${ }^{46,47}$ and Upper Continental Crust (UCC, black square) ${ }^{46,47,64}$ Measured particulate compositions appear to be influenced by excess Nd from seawater (black vertical line in the enlargement). Size of the symbols in the enlargement is scaled to increasing water depth (i.e., larger symbols are from deeper water depth). (B) Same mixing envelope as (A) but with marine particle compositions, corrected for excess $\mathrm{Nd}$ from seawater and color-coded by water depth. Gray stippled lines connect original data points from A (hollow gray symbols) with the new corrected ones, highlighting the shift in the shift in their geochemical composition by seawater influence.

found a similar vertical distribution pattern in $[\mathrm{Nd}]_{\mathrm{p}}$ with $0.44-0.52 \mathrm{pmol} / \mathrm{kg}$ between 500 and $2000 \mathrm{~m}$ as we find in our study $(0.5-0.71 \mathrm{pmol} / \mathrm{kg})$ and strongly elevated values from $4000 \mathrm{~m}$ to the seafloor with $3.31-8.73 \mathrm{pmol} / \mathrm{kg}(3.23-7.09$ $\mathrm{pmol} / \mathrm{kg}$ in our study, Table 2). The intercalibration effort in van de Flierdt et al. ${ }^{30}$ yielded an average $\mathrm{Nd}$ isotope composition of $\varepsilon_{\mathrm{Nd}}^{\mathrm{p}}=-14.2 \pm 1.8$ and $[\mathrm{Nd}]_{\mathrm{p}}$ of $0.29 \pm$ $0.09 \mathrm{pmol} / \mathrm{kg}$ from the five participating laboratories (Table 2). In our study, the isotope composition of particles at 2076 $\mathrm{m}$ depth at station 21 is $\varepsilon_{\mathrm{Nd}}^{\mathrm{p}}=-13.72 \pm 0.26$ and in good agreement with both van de Flierdt et al..$^{30}$ and the $-13.1 \pm$ 0.6 reported by Jeandel et al. ${ }^{27}$

Our $[\mathrm{Nd}]_{\mathrm{p}}$ at $2000 \mathrm{~m}$ of $0.65 \mathrm{pmol} / \mathrm{kg}$ is $\sim 20 \%$ higher than the one reported by Lam et al. $\left([\mathrm{Nd}]_{\mathrm{p}}=0.52 \mathrm{pmol} / \mathrm{kg}\right){ }^{50}$ more than twice as high as that in the intercalibration effort $(0.29 \mathrm{pmol} / \mathrm{kg}$; van de Flierdt et al. $),{ }^{30}$ and about $0.24 \mathrm{pmol} /$ $\mathrm{kg}$ higher than the concentration reported by Jeandel et al. ${ }^{27}$ Even though the good agreement in the isotope compositions is encouraging, the differences observed in $[\mathrm{Nd}]_{\mathrm{p}}$ raise questions on the comparability of the three studies. It can only be speculated what the reason behind the observed discrepancy may be.

Lam et al. ${ }^{50}$ reported particulate metal concentrations from two different size fractions, large sinking particles $(>51 \mu \mathrm{m}$; polyester mesh prefiler) and small suspending particles (0.4$51 \mu \mathrm{m}$; two paired $0.8 \mu \mathrm{m}$ Supor filter, yielding effectively 0.4 $\mu \mathrm{m})$ collected using submersible in situ pumps (McLane). Their $[\mathrm{Nd}]_{\mathrm{p}}$ is however only reported for the smaller fraction above the BNL. The absence of the larger size fraction could therefore contain the "missing" $\sim 20 \%[\mathrm{Nd}]_{\mathrm{p}}$. On the other hand, the broader size fraction collected by van de Flierdt et al. $(>0.45 \mu \mathrm{m}$ Supor filters mounted on McLane pumps; results analyzed in five different laboratories) ${ }^{30}$ should actually yield higher $[\mathrm{Nd}]_{\mathrm{p}}$ than the $>0.8 \mu \mathrm{m}$ filtration we report on here. Jeandel et al. ${ }^{27}$ looked at particle sizes above $1 \mu \mathrm{m}$ on a Nuclepore filter and only reported compositions of their suspended fraction (1-53 $\mu \mathrm{m}$ cutoff) for this sample, so it is possible that the missing $0.8-1 \mu \mathrm{m}$ and $>53 \mu \mathrm{m}$ fractions are causing lower $[\mathrm{Nd}]_{\mathrm{p}}$ values than ours. Besides the utilized filter sizes, the observed differences could also reflect differences in the applied filter protocols, or possibly even temporal variations in the particle loads at this location. It is indeed very plausible that seasonal variability is the cause of this difference in $[\mathrm{Nd}]_{\mathrm{p}}$ as the interannual fluctuations in mass fluxes can vary greatly in the Sargasso $\mathrm{Sea}^{52}$ and all the compared studies report results from different seasons in different years. It thus remains unclear why $[\mathrm{Nd}]_{\mathrm{p}}$ appears to be variable within these four studies and might indicate that particulate compositions are subject to larger variations than the dissolved fraction.

Provenance of Particles in the North Atlantic. The rather extreme $\mathrm{Nd}$ isotope compositions of marine particles at station $2\left(\varepsilon_{\mathrm{Nd}}^{\mathrm{p}}\right.$ up to -3.5$)$ and station $13\left(\varepsilon_{\mathrm{Nd}}^{\mathrm{p}}\right.$ down to -19.7) are likely to reflect the isotope compositions of surrounding land masses (Figure 1B). Sediments in the Labrador Basin are characterized by unradiogenic values as low as $\varepsilon_{\mathrm{Nd}}=-30$ (ref 53), whereas sediments in the Irminger Basin are more radiogenic around $\varepsilon_{\mathrm{Nd}}=-8$ to -4 (refs 53, 54 ). The source of the radiogenic material (with $\varepsilon_{\mathrm{Nd}}$ signatures of +6 to +9 ) to the Irminger Basin can be found in mafic rocks from the Nansen Fjord in East Greenland and Iceland. ${ }^{55,56}$ While the mantle-derived rocks from East Greenland and Iceland are typically low in rare earth element concentrations, with $\mathrm{Nd}$ concentrations of only $2-9 \mathrm{ppm}^{56,57}$ the mafic 
Table 3. Elemental and Isotope Ratios for Reconstruction of Lithogenic Composition

\begin{tabular}{|c|c|c|c|c|c|c|c|c|c|c|c|}
\hline $\begin{array}{l}\text { station } \\
(\#)\end{array}$ & $\begin{array}{c}\text { depth } \\
(\mathrm{m})\end{array}$ & $\begin{array}{l}(\mathrm{Ti} / \mathrm{Nd})_{\mathrm{p}} \\
(\mathrm{mol} / \mathrm{mol})\end{array}$ & $\underset{(\mathrm{nmol} / \mathrm{L})}{[\mathrm{Ti}]_{\mathrm{p}}}$ & $\begin{array}{l}\text { exc. }\left({ }^{231} \mathrm{~Pa} /{ }^{230} \mathrm{Th}\right)_{\mathrm{p}} \\
\text { activity ratio }\end{array}$ & $\begin{array}{l}\text { error } \\
(2 \mathrm{SD})\end{array}$ & $\begin{array}{l}(\mathrm{Ti} / \mathrm{Nd})_{\text {lith }} \\
(\mathrm{mol} / \mathrm{mol})^{a}\end{array}$ & $f_{\mathrm{sw}}^{\mathrm{Nd}}$ & $f_{\text {lith. }}{ }^{\mathrm{Nd}}$ & $\begin{array}{l}\mathrm{Nd}_{\mathrm{SPM}^{-}} \\
\text {nonlith } \\
(\mathrm{ppm})\end{array}$ & $\varepsilon_{\mathrm{Nd}}^{\text {lith }}$ & $\left(\varepsilon_{\mathrm{Nd}} \underset{\text { lith }}{\Delta \varepsilon_{\mathrm{Nd}}^{\text {lith }}}-\varepsilon_{\mathrm{Nd}}^{\mathrm{p}}\right)$ \\
\hline 2 & 556 & 545 & 0.336 & 0.0919 & 0.0162 & 1379 & 0.60 & 0.40 & 4.23 & 3.8 & 10.5 \\
\hline 2 & 1038 & 546 & 0.298 & 0.0798 & 0.0082 & 1326 & 0.59 & 0.41 & 4.01 & 0.5 & 8.2 \\
\hline 2 & 1520 & 613 & 0.661 & 0.0879 & 0.0051 & 1435 & 0.57 & 0.43 & 5.17 & 3.6 & 9.3 \\
\hline 2 & 1906 & 488 & 0.477 & 0.0743 & 0.0050 & 1342 & 0.64 & 0.36 & 6.33 & 1.0 & 8.4 \\
\hline 2 & 2193 & 786 & 4.289 & 0.1120 & 0.0069 & 1574 & 0.50 & 0.50 & 9.14 & 4.6 & 8.2 \\
\hline \multicolumn{12}{|l|}{2} \\
\hline 6 & 611 & 346 & 0.109 & 0.0705 & 0.0079 & 1048 & 0.67 & 0.33 & 2.67 & -16.1 & -1.2 \\
\hline 6 & 1093 & 409 & 0.141 & 0.0664 & 0.0028 & 1008 & 0.59 & 0.41 & 2.16 & -19.6 & -3.4 \\
\hline 6 & 1575 & 417 & 0.179 & 0.0492 & 0.0022 & 1044 & 0.60 & 0.40 & 3.38 & -18.0 & -2.9 \\
\hline 6 & 2539 & & & 0.0569 & 0.0018 & & & & & & \\
\hline 6 & 3079 & 691 & 2.427 & 0.0942 & 0.0036 & 1359 & 0.49 & 0.51 & 5.41 & -3.1 & 4.0 \\
\hline \multicolumn{12}{|l|}{6} \\
\hline 13 & 548 & 206 & 0.177 & 0.0345 & 0.0017 & 418 & 0.51 & 0.49 & 3.99 & -16.1 & -1.7 \\
\hline 13 & 1042 & 250 & 0.214 & 0.0325 & 0.0020 & 475 & 0.47 & 0.53 & 3.56 & -21.4 & -3.3 \\
\hline 13 & 2031 & 470 & 0.398 & 0.0292 & 0.0017 & 505 & 0.07 & 0.93 & 0.71 & -20.2 & -0.5 \\
\hline 13 & 3019 & 379 & 0.282 & 0.0377 & 0.0022 & 491 & 0.23 & 0.77 & 2.42 & -20.9 & -1.9 \\
\hline 13 & 4007 & 391 & 0.530 & 0.0503 & 0.0029 & 475 & 0.18 & 0.82 & 2.35 & -19.4 & -1.2 \\
\hline 13 & 4678 & 418 & 7.473 & 0.0726 & 0.0025 & 471 & 0.11 & 0.89 & 1.59 & -18.6 & -0.7 \\
\hline 21 & 575 & 137 & 0.066 & 0.0152 & 0.0010 & 383 & 0.64 & 0.36 & 4.09 & -12.9 & -1.3 \\
\hline 21 & 1075 & 191 & 0.132 & 0.0326 & 0.0016 & 402 & 0.53 & 0.47 & 4.96 & -13.0 & 0.2 \\
\hline 21 & 2076 & 219 & 0.139 & 0.0284 & 0.0014 & 408 & 0.46 & 0.54 & 4.90 & -14.6 & -0.9 \\
\hline 21 & 3076 & $N / A$ & & & & & & & & & \\
\hline 21 & 4076 & 288 & 0.905 & 0.0382 & 0.0020 & 412 & 0.30 & 0.70 & 5.93 & -14.7 & -0.7 \\
\hline 21 & 4491 & 273 & 1.886 & 0.0403 & 0.0021 & 407 & 0.33 & 0.67 & 5.43 & -14.4 & -0.7 \\
\hline \multicolumn{12}{|l|}{21} \\
\hline 30 & 512 & 272 & 0.226 & 0.0242 & 0.0011 & 389 & 0.30 & 0.70 & 3.64 & -12.7 & -0.5 \\
\hline 30 & 1011 & 314 & 0.309 & 0.0452 & 0.0018 & 386 & 0.19 & 0.81 & 2.37 & -12.0 & 0.0 \\
\hline 30 & 2008 & 316 & 0.186 & 0.0285 & 0.0012 & 392 & 0.19 & 0.81 & 2.36 & -12.4 & 0.1 \\
\hline 30 & 3005 & 314 & 0.178 & 0.0318 & 0.0018 & 394 & 0.20 & 0.80 & 2.74 & -12.7 & -0.1 \\
\hline 30 & 4002 & 301 & 0.144 & 0.0259 & 0.0013 & 396 & 0.24 & 0.76 & 3.33 & -13.0 & -0.2 \\
\hline 30 & 5038 & 299 & 0.339 & 0.0373 & 0.0013 & 388 & 0.23 & 0.77 & 3.79 & -12.4 & -0.2 \\
\hline
\end{tabular}

${ }^{a}$ Parameters to the right: calculated using a mixing model among seawater, Míd-Ocean-Ridge-Basalt, Upper Continental Crust, and Archaean Upper Crust. See text and Figures 6 and 7 for details.

material that erodes from Iceland has particularly high $\mathrm{Nd}$ concentrations: $40-100 \mathrm{ppm}^{56}$ Therefore, even a small detrital contribution from these mafic source rocks can have a large impact on the bulk composition of marine particles local to the area. The mafic dominance of the lithogenic material in the Irminger Basin is likely the reason for the isotope gradient observed between the particle samples retrieved in the Labrador Sea and the Irminger Basin. Marine sediments in the Sargasso Sea are characterized by intermediate $\varepsilon_{\mathrm{Nd}}$ values around -13 (ref 27): higher than the particulates off Newfoundland but lower than the particulates off Iceland/East Greenland and similar to the $\mathrm{Nd}$ isotope composition of Saharan dust. ${ }^{58-62}$

Due to the strong heterogeneity of source rocks around the North Atlantic and their associated Nd concentrations, we cannot simply assume that the lithogenic $\mathrm{Nd}$ concentration in particles, $[\mathrm{Nd}]_{\text {lith }}$, is homogeneous and equal to the average UCC (i.e., $27 \mathrm{ppm}$ ). ${ }^{46}$ Hence, absolute elemental concentrations of $\mathrm{Nd}$ do not seem to be the parameter of choice. We therefore in the following make use of elemental ratios, such as $\mathrm{Ti} / \mathrm{Nd}$ ratios, ${ }^{46,47,63,64}$ to reflect the provenance of lithogenic source material. Given the study area's location, the most appropriate end-members contributing to the marine lithogenic particle compositions are (i) seawater via scavenging $\left(\varepsilon_{\mathrm{Nd}}{ }^{\mathrm{d}}=-9.4 \text { to }-16.7, \mathrm{Ti} / \mathrm{Nd}^{\mathrm{d}}<10\right)^{1,65}$ and (ii) lithogenic input of three different compositions: Mid-Oceanic-RidgeBasalt $\left(\mathrm{MORB}, \varepsilon_{\mathrm{Nd}}=+8.2, \mathrm{Ti} / \mathrm{Nd}=3302\right),{ }^{63}$ Archaean Upper Crust $\left(\mathrm{AUC}, \varepsilon_{\mathrm{Nd}}=-28, \mathrm{Ti} / \mathrm{Nd}=753\right),{ }^{47}$ and UCC $\left(\varepsilon_{\mathrm{Nd}}=\right.$ $-10.5, \mathrm{Ti} / \mathrm{Nd}=369) .{ }^{46,64}$ Figure $6 \mathrm{~A}$ shows a mixing model of $\varepsilon_{\mathrm{Nd}}$ values and $\mathrm{Ti} / \mathrm{Nd}$ ratios for the marine particulates from this study and the four suggested end-members (i.e., three weathering sources and seawater for which a low $\mathrm{Ti} / \mathrm{Nd}$ ratio toward a value of 1 found in the Atlantic $\left.{ }^{1,65}\right)$. Station 2 and the bottom-most sample of station 6 plot within the lithogenic part of the mixing envelope MORB-AUC-UCC, while all other samples plot outside this mixing envelope. The particulate samples near the mixing array AUC-UCC seem to trend toward the composition of seawater in the area (enlargement in Figure 6A), suggesting excess $\mathrm{Nd}$ from scavenging. The symbol size in the enlargement of Figure 6A reflects increasing water depth, indicating that shallower samples are more affected by excess $\mathrm{Nd}$ than the deeper ones.

We can calculate the fraction of this adsorbed $\mathrm{Nd}\left(f_{\mathrm{sw}}\right)$ by applying a ternary mixing model between seawater and two out of the three lithogenic endmembers, MORB and Archaean crust. As outlined in the background geology section, stations in the subpolar gyre (stations 2 and 6) are proximal to MORB and AUC-like lithologies while stations in the subtropical gyre (stations 13, 21, and 30) are likely less influenced by MORB but see more of an input from sources similar to the UCC. 

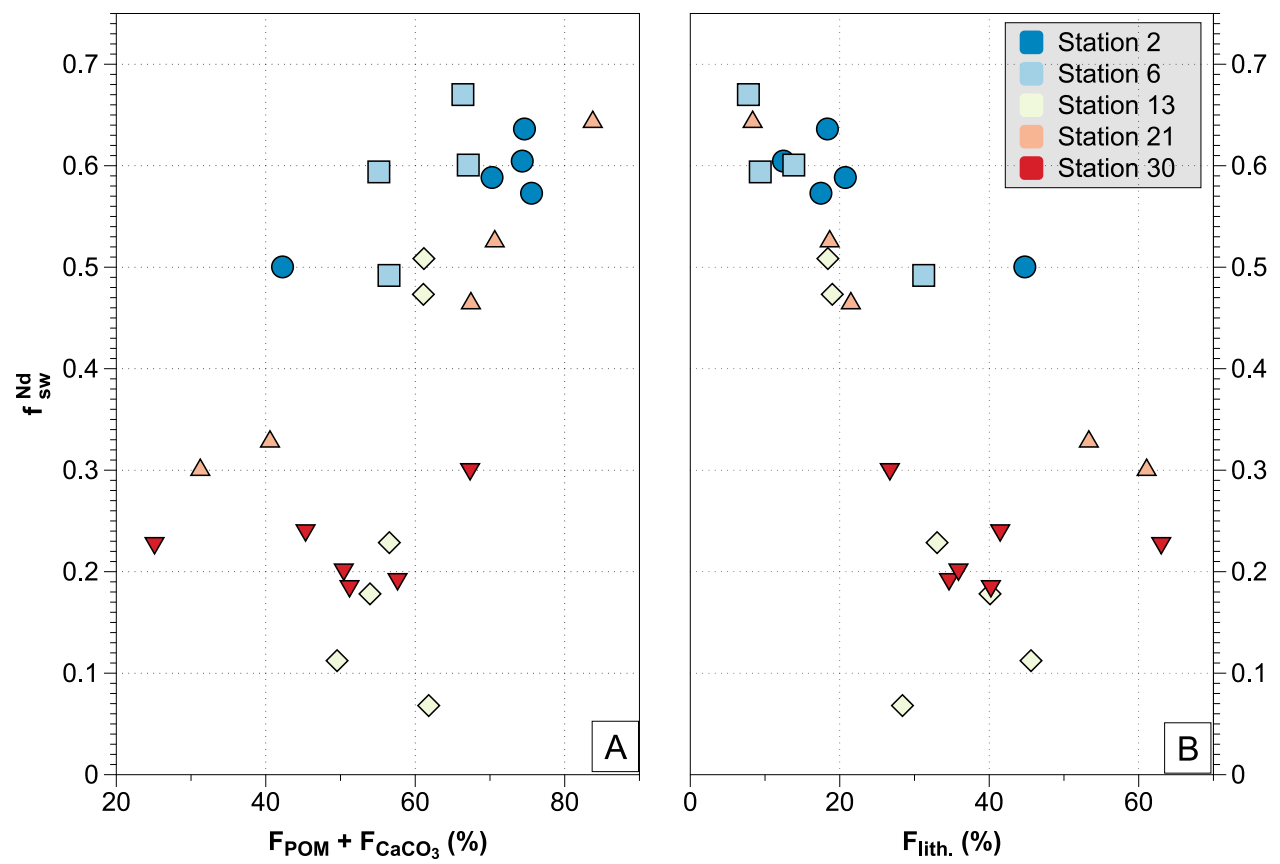

Figure 7. Seawater derived $\mathrm{Nd}$ compared to particle composition. (A) Fraction of seawater derived $\mathrm{Nd}\left(f_{\mathrm{sw}}{ }^{\mathrm{Nd}}\right)$ as a function of combined particulate organic matter (POM) and $\mathrm{CaCO}_{3}$ fractions, suggesting that scavenged $\mathrm{Nd}$ is could be associated with elevated values of the two fractions. This association is accompanied by the regional distribution in the study area, with $f_{\mathrm{sw}}{ }^{\mathrm{Nd}} \geq 0.5$ in the subpolar gyre (station 2 and 6 ). (B) The same $y$-axis as $(\mathrm{A})$ as a function of the lithogenic fraction $\left(f_{\text {lith }}\right)$ calculated from Al content in the particles, showing that lower seawater derived $\mathrm{Nd}$ content is found where higher fractions of lithogenic material are present.

Therefore, samples in the subpolar gyre are likely to be found in a MORB-AUC-seawater space and samples in the subtropical gyre are found in a UCC-AUC-seawater system, acknowledging that AUC may be an end-member of a subordinate role for the south of this area. With this framing, we can solve for each contributing fraction by using the following relationship in the mixing triangles seawater-AUCMORB and seawater-AUC-UCC. We have used the former for stations 2 and 6 and the latter for stations 13, 21, and 30:

$$
\begin{aligned}
& f_{\mathrm{MORB} / \mathrm{UCC}}= \\
& \frac{\left(\frac{\mathrm{Ti}}{\mathrm{Nd}}\right)_{p}-\left(\frac{\mathrm{Ti}}{\mathrm{Nd}}\right)_{\mathrm{AUC}}-f_{\mathrm{sw}}\left(\left(\frac{\mathrm{Ti}}{\mathrm{Nd}}\right)_{\mathrm{sw}}-\left(\frac{\mathrm{Ti}}{\mathrm{Nd}}\right)_{\mathrm{AUC}}\right)}{\left(\frac{\mathrm{Ti}}{\mathrm{Nd}}\right)_{\mathrm{MORB} / \mathrm{UCC}}-\left(\frac{\mathrm{Ti}}{\mathrm{Nd}}\right)_{\mathrm{AUC}}} \\
& f_{\mathrm{AUC}}=\left\{\varepsilon_{\mathrm{Nd}}^{\mathrm{p}}\left(\frac{\mathrm{Ti}}{\mathrm{Nd}}\right)_{\mathrm{p}}-\varepsilon_{\mathrm{Nd}}^{\mathrm{MORB} / \mathrm{UCC}}\left(\frac{\mathrm{Ti}}{\mathrm{Nd}}\right)_{\mathrm{MORB} / \mathrm{UCC}}\right. \\
& \left.-f_{\mathrm{sw}}\left(\varepsilon_{\mathrm{Nd}}^{\mathrm{sw}}\left(\frac{\mathrm{Ti}}{\mathrm{Nd}}\right)_{\mathrm{sw}}-\varepsilon_{\mathrm{Nd}}^{\mathrm{MORB} / \mathrm{UCC}}\left(\frac{\mathrm{Ti}}{\mathrm{Nd}}\right)_{\mathrm{MORB} / \mathrm{UCC}}\right)\right\} \\
& \quad /\left\{\varepsilon_{\mathrm{Nd}}^{\mathrm{AUC}}\left(\frac{\mathrm{Ti}}{\mathrm{Nd}}\right)_{\mathrm{AUC}}-\varepsilon_{\mathrm{Nd}}^{\left.\mathrm{MORB} / \mathrm{UCC}\left(\frac{\mathrm{Ti}}{\mathrm{Nd}}\right)_{\mathrm{MORB} / \mathrm{UCC}}\right\}}\right. \\
& f_{\mathrm{sw}}=1-f_{\mathrm{MORB} / \mathrm{UCC}}-f_{\mathrm{AUC}}
\end{aligned}
$$

Equation 4 can be solved iteratively using a standard goal-seekroutine, and the seawater isotope composition $\left(\varepsilon_{\mathrm{Nd}}{ }^{\mathrm{sw}}\right)$ can be set to the dissolved $\mathrm{Nd}$ results reported by Lambelet et al., ${ }^{1}$ where we again use interpolated values according to our sample depths. With the calculated seawater derived fraction of $\mathrm{Nd}\left(f_{\mathrm{sw}}\right)$ and lithogenic fraction $\left(f_{\text {lith }}=f_{\mathrm{AUC}}+f_{\mathrm{MORB} / \mathrm{UCC}}\right.$ or 1 $\left.-f_{\text {sw }}\right)$, we can estimate the amount of excess $\mathrm{Nd}$ by adsorption and make a suggestion for the most probable $\mathrm{Ti} / \mathrm{Nd}$ ratio of the lithogenic fraction of the marine particles at each station/ water depth (i.e., $\mathrm{Ti} / \mathrm{Nd}_{\text {lith }}$ in Figure $6 \mathrm{~B}$ ) by diving through $f_{\text {lith }}$. The calculated $f_{\text {sw }}$ is important to better understand scavenging of $\mathrm{Nd}$ from seawater, and our data show that in the subpolar gyre at stations 2 and 6 , the average $f_{\text {sw }}$ is with $0.58 \pm 0.06$ nearly twice as high as in the subtropical gyre and station 13 $(0.3 \pm 0.16$, Table 3$)$. It is interesting to note that the high $f_{\text {sw }}$ at stations 2 and 6 are associated with the elevated POM and $\mathrm{CaCO}_{3}$ fractions found in those particles (Figure 7A). The lower $f_{\mathrm{sw}}$ and thus higher $f_{\text {lith }}$ in the remaining stations appears to be controlled by increasing lithogenic content of the particles toward and within the subtropical gyre (Figure 7B). Although the latter may not sound surprising, it appears to indicate that lithogenic particles are less prone to scavenging than $\mathrm{POM}$ or $\mathrm{CaCO}_{3}$ in the North Atlantic.

The $\varepsilon_{\mathrm{Nd}}$ signature of the lithogenic end member $\left(\varepsilon_{\mathrm{Nd}}^{\text {lith }}\right)$ is obtained by solving a simple binary mixing equation by utilizing the measured $\mathrm{Nd}$ isotope composition and concentration of the particulate and seawater, as well as the calculated fractions of adsorbed $\mathrm{Nd}$ onto particles (Figure 6B, Table 3):

$$
\varepsilon_{\mathrm{Nd}}^{\text {lith }}=\frac{\varepsilon_{\mathrm{Nd}}^{\mathrm{p}}[\mathrm{Nd}]_{\mathrm{SPM}}-\varepsilon_{\mathrm{Nd}}^{\mathrm{sw}}[\mathrm{Nd}]_{\mathrm{SPM}} f_{\mathrm{sw}}}{[\mathrm{Nd}]_{\mathrm{SPM}}\left(1-f_{\mathrm{sw}}\right)}
$$

The lithogenic isotope compositions of marine particles along the GA02 transect calculated with eq 5 range from $\varepsilon_{\mathrm{Nd}}$ lith $\approx-22$ (station $13,2031 \mathrm{~m}$ ) to $\varepsilon_{\mathrm{Nd}}^{\text {lith }} \approx+5$ (station 2,2193 $\mathrm{m})$. Stations 21 and 30 yield intermediate values of $\varepsilon_{\mathrm{Nd}}{ }^{\text {lith }}=$ -15 to -12 , which is similar to the $\varepsilon_{\mathrm{Nd}}$ signature of Saharan aerosols. $^{58,61}$ The extremely unradiogenic particulate $\varepsilon_{\mathrm{Nd}}{ }^{\mathrm{p}}$ values between 1 and $3 \mathrm{~km}$ depth at station 13 can be explained if one considers inputs from particles exported from the Labrador Sea, where source rocks can have isotope 
compositions as low as $\varepsilon_{\mathrm{Nd}} \approx-30$ (ref 53), and inputs from surface sediments from the Grand Banks with $\varepsilon_{\mathrm{Nd}}=-26.2$ (ref 66) and are in agreement with our derived $\varepsilon_{\mathrm{Nd}}$ lith of -18 to -22 (Table 3). To conclude, the $\mathrm{Nd}$ composition of marine particulates in the study area is constituted by a mixture between MORB, AUC, and UCC (Figure 6B) and scavenging of seawater-derived $\mathrm{Nd}$. The lithogenic $\mathrm{Nd}$ fraction changes as a result of the varying source rocks around the North Atlantic. The $\varepsilon_{\mathrm{Nd}}$ can change by up to $8-10 \varepsilon_{\mathrm{Nd}}$ units $\left(\Delta \varepsilon_{\mathrm{Nd}}{ }^{\text {lith }}=\varepsilon_{\mathrm{Nd}}{ }^{\mathrm{p}}-\right.$ $\left.\varepsilon_{\mathrm{Nd}}^{\text {lith}}\right)$ at station 2, with more MORB-like provenance, whereas stations 21 and 30 only change marginally $\left(\Delta \varepsilon_{\mathrm{Nd}}{ }^{\text {lith }}\right.$ $<$ 1.4. Table 3).

Significant Lateral Particle Transport within the Subpolar Gyre. The observed vertical structures of $\varepsilon_{\mathrm{Nd}}{ }^{\mathrm{p}}$ in the North Atlantic Ocean, in particular at stations 2, 6, and 13, provide some indications of lateral particle advection. The reason for this suggestion is that particles from a single vertical source with a specific isotope composition falling through the water column should show limited to no variability in $\varepsilon_{\mathrm{Nd}}{ }^{\mathrm{p}}$ and $\varepsilon_{\mathrm{Nd}}{ }^{\text {lith }}$. Even if the particle source is composed of different components (e.g., suspended fluvial material, volcanic ash, or other aerosols), which can each possess unique $\mathrm{Nd}$ isotope compositions and mass fractionates when contained in different grain sizes which are settling through the water column to hypothetically produce vertical gradients in $\varepsilon_{\mathrm{Nd}}$, these gradients are unlikely to form distinct vertical structures. This is, however, not the case, as both $\varepsilon_{\mathrm{Nd}} \mathrm{p}^{\mathrm{p}}$ and $\varepsilon_{\mathrm{Nd}}$ lith change significantly along the vertical profiles in the subpolar gyre (Figures 3 and 6; Table 1). The observed vertical gradients in $\varepsilon_{\mathrm{Nd}}^{\mathrm{p}}$ are best explained by (i) different lateral particle sources or (ii) immediate isotope exchange with water masses, altering the $\mathrm{Nd}$ isotope composition of settling particles. The latter seems not very plausible for most of the samples in our study area, as the isotope range of particles within these profiles is much higher than that of the dissolved fraction (ref 1 and Figure 2). Therefore, it is more plausible that particles are transported horizontally along with water masses. How far this lateral transport can reach along the flow path of water masses is likely to be a function of grain size and flow velocities. For example, the pattern in $\varepsilon_{\mathrm{Nd}}^{\mathrm{p}}$ at station 2 appears to indicate different particle types at different depths. The same pattern is found in the excess particulate ${ }^{231} \mathrm{~Pa} /{ }^{230} \mathrm{Th}$ (ref 67), with ratios close to or higher than their production ratio of 0.093 when $\varepsilon_{\text {Nd }}{ }^{\mathrm{p}}$ shows an increase (Figure $4 \mathrm{~B}$ ). This observation supports the notion that particles from variable sources are present in different depth layers, which result in a changing ${ }^{231} \mathrm{~Pa} /{ }^{230} \mathrm{Th}$ ratios. The rigorous mixing by deep water formation and water mass movement via the Denmark Strait Overflow ${ }^{68,69}$ associated with a very heterogeneous water mass structure ${ }^{70}$ would support $\mathrm{Pa} / \mathrm{Th}$ disequilibrium and thus a variable origin of particles in this region of the study area.

In support of above interpretation, Lambelet et al., ${ }^{1}$ detected LSW and E-NADW (or ISOW) in their dissolved fraction $\left(\varepsilon_{\mathrm{Nd}}^{\mathrm{d}}=-13.2\right.$ and -12.3 , respectively) at the same water depths where the particles show low $\mathrm{Nd}$ isotope values (Figure 3 ; station 2). Along the flow path at stations 6 and 13, the relationship of $\varepsilon_{\mathrm{Nd}}{ }^{\mathrm{p}}$ and excess particulate ${ }^{231} \mathrm{~Pa} /{ }^{230} \mathrm{Th}$ continues but appears less pronounced compared to station 2 ; the minimum $\varepsilon_{\mathrm{Nd}} \mathrm{p}$ of -19.7 at station $13(2031 \mathrm{~m})$ coincides with a minimum in ${ }^{231} \mathrm{~Pa} /{ }^{230} \mathrm{Th}(0.029$, Figure $4 \mathrm{~B})$. Stations 21 and 30 (and the shallowest part of station 13), in contrast, deviate from this correlation between $\varepsilon_{\mathrm{Nd}}{ }^{\mathrm{p}}$ and excess particulate ${ }^{231} \mathrm{~Pa} /{ }^{230} \mathrm{Th}$ and display relatively narrow ranges in both isotope systems suggesting a different source and/or an isotope homogenization with transport time (Figure 4B).

Advection of Particles vs Vertical Settling: The NADW Depth Layer. An important aspect of the interplay of particulate and dissolved phases in the ocean is the time which particles have spent and can spend in the water column. Recent studies have suggested that particle exchange for some trace metals happens nearly instantly when weathered material enters seawater along salinity gradients. ${ }^{19,71,72}$ However, whether particle-seawater exchange still occurs beyond these proximal settings where (sea)water acquires a weathering signal (i.e., in areas of lower particle concentrations away from ocean margins) remains an open question.

To address this question, we can look at the difference in $\mathrm{Nd}$ isotope compositions $\left(\Delta \varepsilon_{\mathrm{Nd}}\right)$ between the dissolved and particulate phases along the NADW flow path, which was sampled along the GA02 transect (Figure 1A). The age of the water masses can be estimated by the dissolved ${ }^{231} \mathrm{~Pa}$ inventory. The underlying principle is the fact that the source term for ${ }^{231} \mathrm{~Pa}$ in the water column is known very precisely. This radioactive isotope is constantly generated from ${ }^{235} \mathrm{U}$, a component of sea salt, as a function of time. During the formation of NADW, water very low in ${ }^{231} \mathrm{~Pa}$ is brought to depth, and the gradual ingrowth of this isotope along its flowpath from a value close to zero can be translated into a travel time. This approach yields transport times of 20 years from station 6 south of Greenland to station 30 off the West Indies (ref 73). Comparing $\Delta \varepsilon_{\mathrm{Nd}}$ to the transport time of 16 years ${ }^{73}$ between stations 13 and 30, it appears that particles become fully equilibrated with ambient seawater in their $\mathrm{Nd}$ isotope composition by the time they reach station 30 , as indicated by indistinguishable isotope fingerprints (Figures 3 and 4D). Alternatively, low $\Delta \varepsilon_{\mathrm{Nd}}$ could also be the result of indistinguishable $\mathrm{Nd}$ isotope compositions of local (i.e., vertical) lithogenic inputs (i.e., source rocks) and seawater.

To address this issue, we can calculate whether the horizontal flux of particles and their $\mathrm{Nd}$ inventory at core NADW depths of $1-3 \mathrm{~km}$ between station 13,21 , and 30 is fast enough to keep particles in suspension before they settle down, or whether vertical settling of particles still plays an important role. The settling rate $(S)$ of particles can be estimated by the particulate excess ${ }^{230} \mathrm{Th}$ compared to the production rate $(P)$ of this isotope by the decay of ${ }^{234} \mathrm{U}$ $\left(0.0262 \mathrm{dpm} / \mathrm{m}^{3} /\right.$ year $): S=\left(P /{ }^{230} \mathrm{Th}_{\mathrm{xsp}}\right) z$, with $z$ as the depth interval. $^{74}$ The calculation yields a settling rate of 450 to 1300 $\mathrm{m} /$ year at these 3 stations between 1 and $3 \mathrm{~km}$ water depth (Figure S-3 and Table S-6). Using $[\mathrm{Nd}]_{\mathrm{p}}$ per volume of seawater (i.e., $\mathrm{nmol} / \mathrm{m}^{3}$ ) within the $1-3 \mathrm{~km}$ depth interval and $S$, the vertical flux $\left(F_{\mathrm{v}}^{\mathrm{Nd}}=[\mathrm{Nd}]_{\mathrm{p}} S\right)$ of particulate $\mathrm{Nd}$ would be around 389 to $927 \mathrm{nmol} / \mathrm{m}^{2} /$ year. In order for this vertical flux to now have an impact on the inventory of particulates in the water column, we need to know the horizontal flux of particles and their $\mathrm{Nd}$ inventory. The horizontal flux $\left(F_{\mathrm{h}}{ }^{\mathrm{Nd}}\right)$ can be estimated using the water mass velocity derived from the age and distance between the stations of $230 \mathrm{~km} /$ year. With this, $F_{\mathrm{h}}{ }^{\mathrm{Nd}}$ would be as high as $2.3 \times 10^{5} \mathrm{nmol} / \mathrm{m}^{2} /$ year and thus 180-500 times higher than $F_{\mathrm{v}}^{\mathrm{Nd}}$. However, the actual particulate inventories at the NADW level (i.e., $1-3 \mathrm{~km}$ water depth) at stations 13, 21, and 30 are about 1630, 1330, and $1420 \mathrm{nmol} / \mathrm{m}^{2}$ (Table S-7), respectively, which is much lower than the estimated horizontal supply, $F_{\mathrm{h}} \mathrm{Nd}$.

This indicates that the main driver in the subtropical water column's particulate $\mathrm{Nd}$ budget is the vertical supply and 

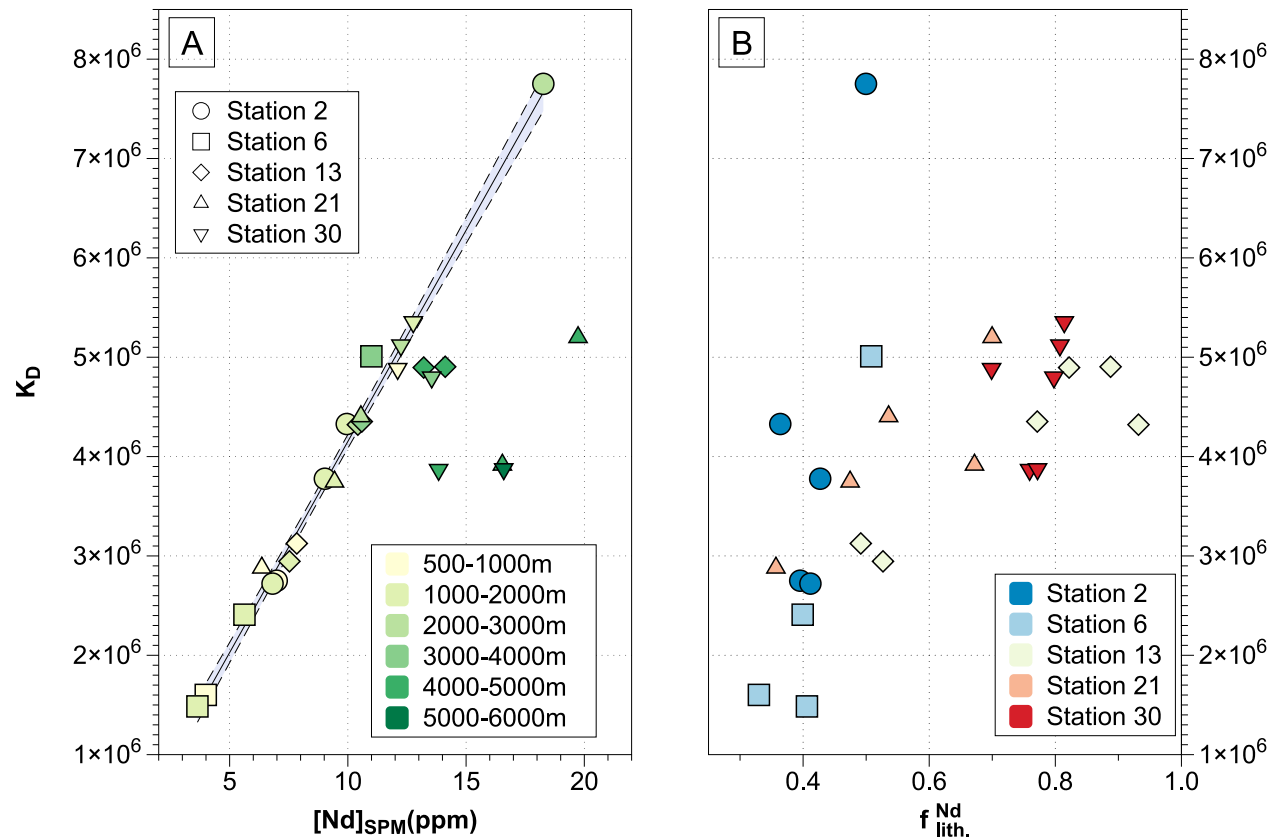

Figure 8. (A) Equilibrium partition coefficient $K_{\mathrm{D}}$ defined as $K_{\mathrm{D}}=[\mathrm{Nd}]_{\mathrm{SPM}} /[\mathrm{Nd}]_{\mathrm{d}} \rho$ versus the $\mathrm{Nd}$ concentration in suspended particulate matter $\left[\mathrm{Nd}_{\mathrm{SPM}}\right]$ along the GA02 transect. There is a clear positive correlation, which only breaks down for the deepest water depths of samples from the subtropical region. Symbols correspond to station locations (see previous figures) and bounds in the trend are set to $95 \%$ confidence, disregarding samples deeper than $3 \mathrm{~km}$. (B) Equilibrium partition coefficient $K_{\mathrm{D}}$ versus the lithogenic $\mathrm{Nd}$ fraction in marine particulate samples along the GA02 transect. Broadly speaking, the samples that fall off the positive correlation line in panel (A) are the samples with lithogenic Nd fractions larger than $\sim 50 \%$ (panel B).

removal through the water column rather than the lateral contribution. The estimated vertical residence time of particles in NADW $(z / S)$ is between 4.4 and 1.5 years, which is short enough to exchange the particulate $\mathrm{Nd}$ inventory within a distance of $1000 \mathrm{~km}$ or less when multiplied by the estimated water mass velocity. These estimates and the isotopic homogeneity suggest that particles at stations 21 and 30 are not necessarily transported along the flow path of NADW but merely supplied vertically. This interpretation clearly deviates from the one for the subpolar gyre discussed above (stations 2, 6 , and 13), where the particulate composition is more readily explained by an additional horizontal component.

The Role of Reversible Scavenging the Subtropical Gyre. Particle-seawater exchange by settling particles should broadly be governed by reversible scavenging. By this we mean the balance of scavenged $\mathrm{Nd}$ onto particles and their release by disaggregation or dissolution. The reversible scavenging model proposed in other studies ${ }^{75,76}$ has a number of assumptions. First, this model is a one-dimensional approach that considers only particulates that settle vertically through the water column, and neglects potential horizontal advection. Second, the system is in a steady state, meaning that external fluxes from particles are balanced by dissolution and adsorption, with a portioning that is set by the equilibrium scavenging constant, $K_{\mathrm{D}}=\frac{[\mathrm{Nd}]_{]_{P M}}^{\mathrm{p}}}{[\mathrm{Nd}]^{\mathrm{d}}} \rho(\rho=$ density of seawater $)$. In the case of our study, this would mean that $\mathrm{Nd}$ concentrations in particles $\left([\mathrm{Nd}]_{\mathrm{SPM}}\right)$ would ultimately be set by changes in dissolved $\mathrm{Nd}$ via adsorption or dissolution, a boundary exchange on microscales. Therefore, either total SPM and $[\mathrm{Nd}]_{\mathrm{p}}$ are expected to not change with depth (as long as the dissolved $\mathrm{Nd}$ concentration does not change) or their quantities may change in a way to maintain the " $K_{\mathrm{D}}$ " invariant.
However, our new data set reveals a number of observations that are not compatible with this simplistic view. First, there is some degree of variability in $[\mathrm{Nd}]_{\mathrm{p}}$ and SPM within the water column at most of the stations. Except for the deepest samples at each station, where $[\mathrm{Nd}]_{\mathrm{p}}$ and SPM increase between 2 and 20 -fold due to the presence of a BNL, the variation of $[\mathrm{Nd}]_{\mathrm{p}}$ and SPM small. Second, $[\mathrm{Nd}]_{\mathrm{d}}$ increases significantly below $3000 \mathrm{~m}^{1}$ (Table S-3).

Another way of looking at the problem is presented in Figure 8, which reveals a clear positive correlation between $[\mathrm{Nd}]_{\mathrm{SPM}}$ and the equilibrium scavenging constant $K_{\mathrm{D}}$. Interestingly, this correlation breaks down for samples for which $[\mathrm{Nd}]_{\mathrm{d}}$ shows a pronounced linear increase with depth (i.e., samples at $>3000 \mathrm{~m}$ water depths at subtropical stations 21 and 30, and samples at $>4000 \mathrm{~m}$ water depth at station 13 ). One interpretation could be that samples along the trend of increasing $[\mathrm{Nd}]_{\mathrm{SPM}}$ and $K_{\mathrm{D}}$, which share a relatively invariant $[\mathrm{Nd}]_{\mathrm{d}}$ (Table S-3 and Lambelet et al.), are not subject to reversible scavenging. Instead, $K_{\mathrm{D}}$ appears to be a function of increasing $[\mathrm{Nd}]_{\text {SPM }}$ (Figure 8 ). The deep samples in the subtropical gyre, characterized by increases in $[\mathrm{Nd}]_{\mathrm{d}}$, deviate from this trend suggesting that particles and seawater appear to begin equilibrating at approximately constant $K_{\mathrm{D}}$ values of $4-6$ $\times 10^{6}$. This suggests either (i) that the adsorption of $\mathrm{Nd}$ onto particles does not increase any further and $[\mathrm{Nd}]_{\mathrm{d}}$ is allowed to increase due to reduced scavenging potential, or (ii) that increasing $[\mathrm{Nd}]_{\mathrm{d}}$ is of a different origin, such as a previous neglected source of $\mathrm{Nd}$ (e.g., preformed $\mathrm{Nd}$, benthic flux) or pool of $\mathrm{Nd}$ (e.g., the presence of particles small enough to pass the filter defining the dissolved fraction). Future studies on specific $K_{\mathrm{D}}$ 's in single particle type (lithogenic, $\mathrm{CaCO}_{3}, \mathrm{POM}$, $\mathrm{BSi}, \mathrm{MnO}_{2}, \mathrm{Fe}(\mathrm{OH})_{2}$, etc.) and size fractions will be needed to constrain the details of the $\mathrm{Nd}$ source/pool. 


\section{CONCLUSION}

We presented the first regional data set of particulate and dissolved $\mathrm{Nd}$ concentrations and isotope compositions from the subpolar and subtropical North Atlantic. Using our geochemical data, we also estimated single fractions (particulate organic matter, biogenic $\mathrm{Si}, \mathrm{Fe}-\mathrm{Mn}$ oxides, $\mathrm{CaCO}_{3}$, and lithogenic material) to compose suspended matter (SPM). Particulate $\mathrm{Nd}$ concentrations $\left([\mathrm{Nd}]_{\mathrm{p}}\right)$ are rather invariant throughout the water column as opposed to the strongly elevated values found near the seafloor for all but one station. Close to the seafloor, $[\mathrm{Nd}]_{\mathrm{p}}$ can be almost as high as previously reported dissolved $\mathrm{Nd}$ concentrations. Our new particulate results show that particle compositions for lithogenic elements like $\mathrm{Nd}$ are significantly influenced by the isotopic composition of proximal landmasses and hence vary with geographically distinct source regions. With a mixing model, we were able to deconvolute the lithogenic composition of particles, i.e., the fraction that is not influenced by $\mathrm{Nd}$ from seawater. Seawater derived Nd was estimated to be as much as $60 \%$ in the particulate $\mathrm{Nd}$ in the subpolar gyre, while the subtropical gyre's particles showed only about half of that. We also observed a pronounced vertical structure in particulate $\mathrm{Nd}$ isotope composition in the subpolar gyre, which can be explained with later advection of particles as supported by excess ${ }^{231} \mathrm{~Pa} /{ }^{230} \mathrm{Th}$ in particulates. In contrast, a more homogeneous structure of particulate $\mathrm{Nd}$ isotope composition was found in the subtropical gyre, where isotope compositions are indistinguishable from the dissolved seawater $\mathrm{Nd}$ isotope signal. A tempting interpretation would be to assume that particulates assimilate as seawater signal along the flow path of the core of NADW. However, calculated vertical particulate $\mathrm{Nd}$ fluxes, derived from excess particulate ${ }^{230} \mathrm{Th}$, revealed that the particle inventory in the subtropical gyre is exchanged in less than 5 years as opposed to an advection time scale of $\sim 20$ years, contradicting the possibility of seawater assimilation. It seems more plausible that a different source of particles (e.g., dust) is introduced into the subtropical gyre, with an isotope composition matching that of local seawater. We also find a missing correlation of $K_{\mathrm{D}}$ (the ratio of [Nd] in SPM over dissolved $\mathrm{Nd}$ ) with $\mathrm{Nd}_{\mathrm{SPM}}$ in the deep subtropical gyre, where dissolved $\mathrm{Nd}$ increases with depth. At this depth, lithogenic content in the particles is higher than 50\%, which appears to be a threshold for leveling out scavenging, allowing an increase in dissolved $\mathrm{Nd}$ with depth. In order to fully resolve the role of particulate-seawater interaction in explaining increases in dissolved $\mathrm{Nd}$ concentrations in the deep subtropical Atlantic ( $>3 \mathrm{~km}$, Lambelet et al.), more research on size fractionated particulate and dissolved samples, including measurements on the colloidal and truly dissolved fractions, are needed to fully unravel the marine biogeochemical cycle of $\mathrm{Nd}$.

\section{ASSOCIATED CONTENT}

\section{(5) Supporting Information}

The Supporting Information is available free of charge at https://pubs.acs.org/doi/10.1021/acsearthspacechem.0c00034.

Major particulate compositions of the five stations; actual and interpolated values for dissolved $\mathrm{Nd}$; settling velocity estimated from excess ${ }^{230} \mathrm{Th}$; tables as described for the XLSX file (PDF)

Tables showing spike compositions used for isotope dilution, components of major particulate and parame- ters to calculate the components, comparison of major particulate composition, particulate $\mathrm{Nd}$ data, comparison of particulate $\mathrm{Nd}$ and isotope concentrations, estimates of settling velocity, and inventory of different stations at various water depths (XLSX)

\section{AUTHOR INFORMATION}

\section{Corresponding Author}

Torben Stichel - Department of Earth Science and Engineering, Imperial College London, London SW7 2AZ, United Kingdom; Alfred Wegener Institute, Helmholtz-Centre for Polar and Marine Research, 27570 Bremerhaven, Germany; 이이. org/ 0000-0002-5925-1301; Email: torben.stichel@awi.de

\section{Authors}

Sven Kretschmer - Alfred Wegener Institute, Helmholtz-Centre for Polar and Marine Research, 27570 Bremerhaven, Germany Walter Geibert - Alfred Wegener Institute, Helmholtz-Centre for Polar and Marine Research, 27570 Bremerhaven, Germany

Myriam Lambelet - Department of Earth Science and Engineering, Imperial College London, London SW7 2AZ, United Kingdom

Yves Plancherel - Grantham Institute - Climate Change and the Environment, Imperial College London, London SW7 2AZ, United Kingdom

Michiel Rutgers van der Loeff - Alfred Wegener Institute, Helmholtz-Centre for Polar and Marine Research, 27570 Bremerhaven, Germany

Tina van de Flierdt - Department of Earth Science and Engineering, Imperial College London, London SW7 2AZ, United Kingdom

Complete contact information is available at: https://pubs.acs.org/10.1021/acsearthspacechem.0c00034

\section{Notes}

The authors declare no competing financial interest.

\section{ACKNOWLEDGMENTS}

The authors would like to thank the crew of RV Pelagia during expedition PE319 and PE321 and the chief scientists L. J. A. Gerringa (leg 1), M. J. A. Rijkenberg (leg 2), and H.J.W. de Baar for their support. O. Lechtenfeld is thanked for the pump operation on PE-321. Three anonymous reviewers are acknowledged for their helpful suggestions to significantly improve this paper. We also like to thank K. Kreissig and B. Coles for their lab support at Imperial College London as well as I. Stimac at AWI. This project was funded by NERC Grant NE/J021636/1 to T.vdF. The authors acknowledge support by the Open Access Publication Funds of Alfred-Wegener-Institut Helmholtz-Zentrum für Polar- und Meeresforschung.

\section{REFERENCES}

(1) Lambelet, M.; van de Flierdt, T.; Crocket, K.; Rehkämper, M.; Kreissig, K.; Coles, B.; Rijkenberg, M. J. A.; Gerringa, L. J. A.; de Baar, H. J. W.; Steinfeldt, R. Neodymium Isotopic Composition and Concentration in the Western North Atlantic Ocean: Results from the GEOTRACES GA02 Section. Geochim. Cosmochim. Acta 2016, 177, $1-29$.

(2) Jacobsen, S. B.; Wasserburg, G. J. Sm-Nd Isotopic Evolution of Chondrites. Earth Planet. Sci. Lett. 1980, 50, 139-155.

(3) Piepgras, D. J.; Wasserburg, G. J. Isotopic Composition of Neodymium in Waters from the Drake Passage. Science 1982, 217 (4556), 207-214. 
(4) Jeandel, C. Concentration and Isotopic Composition of $\mathrm{Nd}$ in the South Atlantic Ocean. Earth Planet. Sci. Lett. 1993, 117 (3-4), 581-591.

(5) Lacan, F.; Jeandel, C. Acquisition of the Neodymium Isotopic Composition of the North Atlantic Deep Water. Geochem., Geophys., Geosyst. 2005, 6, 12.

(6) von Blanckenburg, F. PALEOCEANOGRAPHY:Tracing Past Ocean Circulation? Science (Washington, DC, U. S.) 1999, 286 (5446), $1862 \mathrm{~b}-1863$.

(7) Piotrowski, A. M.; Goldstein, S. L.; Hemming, S. R.; Fairbanks, R. G. Intensification and Variability of Ocean Thermohaline Circulation through the Last Deglaciation. Earth Planet. Sci. Lett. 2004, 225 (1-2), 205-220.

(8) Roberts, N. L.; Piotrowski, A. M.; McManus, J. F.; Keigwin, L. D. Synchronous Deglacial Overturning and Water Mass Source Changes. Science 2010, 327 (5961), 75-78.

(9) Bohm, E.; Lippold, J.; Gutjahr, M.; Frank, M.; Blaser, P.; Antz, B.; Fohlmeister, J.; Frank, N.; Andersen, M. B.; Deininger, M. Strong and Deep Atlantic Meridional Overturning Circulation during the Last Glacial Cycle. Nature 2015, 517 (7532), 73-76.

(10) Pöppelmeier, F.; Gutjahr, M.; Blaser, P.; Keigwin, L. D.; Lippold, J. Origin of Abyssal NW Atlantic Water Masses Since the Last Glacial Maximum. Paleoceanogr. Paleoclimatology 2018, 33 (5), 530-543.

(11) Basak, C.; Fröllje, H.; Lamy, F.; Gersonde, R.; Benz, V.; Anderson, R. F.; Molina-Kescher, M.; Pahnke, K. Breakup of Last Glacial Deep Stratification in the South Pacific. Science (Washington, DC, U. S.) 2018, 359 (6378), 900-904.

(12) van de Flierdt, T.; Frank, M.; Halliday, A. N.; Hein, J. R.; Hattendorf, B.; Günther, D.; Kubik, P. W. Deep and Bottom Water Export from the Southern Ocean to the Pacific over the Past 38 Million Years. Paleoceanography 2004, 19 (1), PA1020.

(13) Lang, D. C.; Bailey, I.; Wilson, P. A.; Chalk, T. B.; Foster, G. L.; Gutjahr, M. Incursions of Southern-Sourced Water into the Deep North Atlantic during Late Pliocene Glacial Intensification. Nat. Geosci. 2016, 9 (5), 375-379.

(14) Scher, H. D.; Whittaker, J. M.; Williams, S. E.; Latimer, J. C.; Kordesch, W. E. C.; Delaney, M. L. Onset of Antarctic Circumpolar Current 30 Million Years Ago as Tasmanian Gateway Aligned with Westerlies. Nature 2015, 523 (7562), 580-583.

(15) Rempfer, J.; Stocker, T. F.; Joos, F.; Dutay, J.-C.; Siddall, M. Modelling Nd-Isotopes with a Coarse Resolution Ocean Circulation Model: Sensitivities to Model Parameters and Source/Sink Distributions. Geochim. Cosmochim. Acta 2011, 75 (20), 5927-5950.

(16) Siddall, M.; Khatiwala, S.; van de Flierdt, T.; Jones, K.; Goldstein, S. L.; Hemming, S.; Anderson, R. F. Towards Explaining the Nd Paradox Using Reversible Scavenging in an Ocean General Circulation Model. Earth Planet. Sci. Lett. 2008, 274 (3-4), 448-461.

(17) Arsouze, T.; Dutay, J.-C.; Lacan, F.; Jeandel, C. Reconstructing the Nd Oceanic Cycle Using a Coupled Dynamical - Biogeochemical Model. Biogeosciences 2009, 6 (12), 2829-2846.

(18) Zheng, X. Y.; Plancherel, Y.; Saito, M. A.; Scott, P. M.; Henderson, G. M. Rare Earth Elements (REEs) in the Tropical South Atlantic and Quantitative Deconvolution of Their Non-Conservative Behavior. Geochim. Cosmochim. Acta 2016, 177, 217-237.

(19) Jeandel, C.; Peucker-Ehrenbrink, B.; Jones, M. T.; Pearce, C. A.; Oelkers, E. H.; Godderis, Y.; Lacan, F.; Aumont, O.; Arsouze, T. Ocean Margins: The Missing Term in Oceanic Element Budgets? EOS, Trans. Am. Geophys. Union 2011, 92 (26), 217-222.

(20) Arsouze, T.; Dutay, J.; Lacan, F.; Jeandel, C. Modeling the Neodymium Isotopic Composition with a Global Ocean Circulation Model. Chem. Geol. 2007, 239 (1-2), 165-177.

(21) Jeandel, C.; Arsouze, T.; Lacan, F.; Techine, P.; Dutay, J. C. Isotopic $\mathrm{Nd}$ Compositions and Concentrations of the Lithogenic Inputs into the Ocean: A Compilation, with an Emphasis on the Margins. Chem. Geol. 2007, 239 (1-2), 156-164.

(22) Tachikawa, K.; Jeandel, C.; Roy-Barman, M. A New Approach to the Nd Residence Time in the Ocean: The Role of Atmospheric Inputs. Earth Planet. Sci. Lett. 1999, 170 (4), 433-446.
(23) Stichel, T.; Hartman, A. E.; Duggan, B.; Goldstein, S. L.; Scher, H.; Pahnke, K. Separating Biogeochemical Cycling of Neodymium from Water Mass Mixing in the Eastern North Atlantic. Earth Planet. Sci. Lett. 2015, 412, 245-260.

(24) Lacan, F.; Jeandel, C. Tracing Papua New Guinea Imprint on the Central Equatorial Pacific Ocean Using Neodymium Isotopic Compositions and Rare Earth Element Patterns. Earth Planet. Sci. Lett. 2001, 186 (3-4), 497-512.

(25) Bertram, C. J.; Elderfield, H. The Geochemical Balance of the Rare Earth Elements and Neodymium Isotopes in the Oceans. Geochim. Cosmochim. Acta 1993, 57 (9), 1957-1986.

(26) Goldstein, S. L.; Hemming, S. R. Long-Lived Isotopic Tracers in Oceanography, Paleoceanography, and Ice-Sheet Dynamics. In Treatise on Geochemistry: The Oceans and Marine Geochemistry; Holland, H. D., Turekian, K., Elderfield, H., Eds.; Elsevier Ltd, 2003; pp 453-489.

(27) Jeandel, C.; Bishop, J. K.; Zindler, A. Exchange of Neodymium and Its Isotopes between Seawater and Small and Large Particles in the Sargasso Sea. Geochim. Cosmochim. Acta 1995, 59 (3), 535-547.

(28) Tachikawa, K.; Handel, C.; Dupré, B. Distribution of Rare Earth Elements and Neodymium Isotopes in Settling Particulate Material of the Tropical Atlantic Ocean (EUMELI Site). Deep Sea Res., Part I 1997, 44 (11), 1769-1792.

(29) Tachikawa, K.; Jeandel, C.; Vangriesheim, A.; Dupré, B. Distribution of Rare Earth Elements and Neodymium Isotopes in Suspended Particles of the Tropical Atlantic Ocean (EUMELI Site). Deep Sea Res., Part I 1999, 46 (5), 733-755.

(30) van de Flierdt, T.; Pahnke, K.; Amakawa, H.; Andersson, P.; Basak, C.; Coles, B.; Colin, C.; Crocket, K.; Frank, M.; Frank, N.; Goldstein, S. L.; Goswami, V.; Haley, B. A.; Hathorne, E. C.; Hemming, S. R.; Henderson, G. M.; Jeandel, C.; Jones, K.; Kreissig, K.; Lacan, F.; Lambelet, M.; Martin, E. E.; Newkirk, D. R.; Obata, H.; Pena, L.; Piotrowski, A. M.; Pradoux, C.; Scher, H. D.; Schöberg, H.; Singh, S. K.; Stichel, T.; Tazoe, H.; Vance, D.; Yang, J. GEOTRACES Intercalibration of Neodymium Isotopes and Rare Earth Element Concentrations in Seawater and Suspended Particles. Part 1: Reproducibility of Results for the International Intercomparison. Limnol. Oceanogr.: Methods 2012, 10 (4), 234-251.

(31) Schmitz, W. J. On the Interbasin-Scale Thermohaline Circulation. Rev. Geophys. 1995, 33 (2), 151.

(32) Smethie, W. M.; Lebel, D. A.; Fine, R. A. Strength and Variability of the Deep Limb of the North Atlantic Meridional Overturning Circulation From Chlorofluorocarbon Inventories. In Ocean. Geophys. Monogr. 2007, 173, 119-130.

(33) Swift, J. H. The Circulation of the Denmark Strait and IcelandScotland Overflow Waters in the North Atlantic. Deep-Sea Res., Part A 1984, 31 (11), 1339-1355.

(34) Sy, A.; Rhein, M.; Lazier, J. R. N.; Koltermann, K. P.; Meincke, J.; Putzka, A.; Bersch, M. Surprisingly Rapid Spreading of Newly Formed Intermediate Waters across the North Atlantic Ocean. Nature 1997, 386 (6626), 675-679.

(35) Smethie, W. M.; Fine, R. a; Putzka, A.; Jones, E. P. Tracing the Flow of North Atlantic Deep Water Using Chlorofluorocarbons. J. Geophys. Res. Ocean. 2000, 105 (C6), 14297-14323.

(36) Fine, R. A.; Rhein, M.; Andrié, C. Using a CFC Effective Age to Estimate Propagation and Storage of Climate Anomalies in the Deep Western North Atlantic Ocean. Geophys. Res. Lett. 2002, 29 (24), 801 .

(37) Tomczak, M.; Godfrey, J. S. Hydrology of the Atlantic Ocean. Regional Oceanography 2003, 2, 253-270.

(38) St-Onge, M. R.; Van Gool, J. a. M.; Garde, A. a.; Scott, D. J. Correlation of Archaean and Palaeoproterozoic Units between Northeastern Canada and Western Greenland: Constraining the Pre-Collisional Upper Plate Accretionary History of the TransHudson Orogen. Geol. Soc. Spec. Publ. 2009, 318 (1), 193-235.

(39) Henriksen, N.; Higgins, A. K.; Kalsbeek, F.; Pulvertaft, T. C. R. Greenland from Archaean to Quaternary Descriptive Text to the 1995 Geological Map of Greenland 1:2 500 000. Geol. Surv. Den. Greenl. Bull. 2009, 18, 126. 
(40) Anderson, R. F.; Fleisher, M. Q.; Robinson, L. F.; Edwards, R. L.; Hoff, J. A.; Moran, S. B.; van der Loeff, M. R.; Thomas, A. L.; RoyBarman, M.; Francois, R. GEOTRACES Intercalibration of 230Th, 232Th, $231 \mathrm{~Pa}$, and Prospects for 10Be. Limnol. Oceanogr.: Methods 2012, 10, 179-213.

(41) Anderson, R. F.; Fleer, A. P. Determination of Natural Actinides and Plutonium in Marine Particulate Material. Anal. Chem. 1982, 54 (7), 1142-1147.

(42) Crocket, K. C.; Lambelet, M.; van de Flierdt, T.; Rehkämper, M.; Robinson, L. F. Measurement of Fossil Deep-Sea Coral Nd Isotopic Compositions and Concentrations by TIMS as $\mathrm{NdO}+$, with Evaluation of Cleaning Protocols. Chem. Geol. 2014, 374-375, 128140.

(43) Struve, T.; van de Flierdt, T.; Robinson, L. F.; Bradtmiller, L. I.; Hines, S. K.; Adkins, J. F.; Lambelet, M.; Crocket, K. C.; Kreissig, K.; Coles, B.; Auro, M. E. Neodymium Isotope Analyses after Combined Extraction of Actinide and Lanthanide Elements from Seawater and Deep-Sea Coral Aragonite. Geochem., Geophys., Geosyst. 2016, 17 (1), 232-240.

(44) Tanaka, T.; Togashi, S.; Kamioka, H.; Amakawa, H.; Kagami, H.; Hamamoto, T.; Yuhara, M.; Orihashi, Y.; Yoneda, S.; Shimizu, H.; Kunimaru, T.; Takahashi, K.; Yanagi, T.; Nakano, T.; Fujimaki, H.; Shinjo, R.; Asahara, Y.; Tanimizu, M.; Dragusanu, C. JNdi-1: A Neodymium Isotopic Reference in Consistency with LaJolla Neodymium. Chem. Geol. 2000, 168 (3-4), 279-281.

(45) Weis, D.; Kieffer, B.; Maerschalk, C.; Barling, J.; De Jong, J.; Williams, G. a.; Hanano, D.; Pretorius, W.; Mattielli, N.; Scoates, J. S.; Goolaerts, A.; Friedman, R. M.; Mahoney, J. B. High-Precision Isotopic Characterization of USGS Reference Materials by TIMS and MC-ICP-MS. Geochem., Geophys,. Geosyst. 2006, 7, 8.

(46) Rudnick, R. L.; Gao, S. Composition of the Continental Crust. In Treatise on Geochemistry; Elsevier, 2003; Vol. 3, pp 1-64.

(47) Taylor, S. R.; McLennan, S. M. The Continental Crust: Its Composition and Evolution; Blackwell: Malden, MA, 1985.

(48) Lam, P. J.; Bishop, J. K. B. High Biomass, Low Export Regimes in the Southern Ocean. Deep Sea Res., Part II 2007, 54 (5-7), 601638.

(49) Pilson, M. E. Q. An Introduction to the Chemistry of the Sea, 2nd ed.; Cambridge University Press, New York, 2013.

(50) Lam, P. J.; Ohnemus, D. C.; Auro, M. E. Size-Fractionated Major Particle Composition and Concentrations from the US GEOTRACES North Atlantic Zonal Transect. Deep Sea Res., Part II 2015, 116, 303-320.

(51) Lam, P. J.; Doney, S. C.; Bishop, J. K. B. The Dynamic Ocean Biological Pump: Insights from a Global Compilation of Particulate Organic Carbon, $\mathrm{CaCO} 3$, and Opal Concentration Profiles from the Mesopelagic. Global Biogeochem. Cycles 2011, 25 (3), GB3009.

(52) Conte, M. H.; Carter, A. M.; Koweek, D. A.; Huang, S.; Weber, J. C. The Elemental Composition of the Deep Particle Flux in the Sargasso Sea. Chem. Geol. 2019, 511 (October 2018), 279-313.

(53) Innocent, C.; Fagel, N.; Stevenson, R. K.; Hillaire-Marcel, C. Sm-Nd Signature of Modern and Late Quaternary Sediments from the Northwest North Atlantic: Implications for Deep Current Changes since the Last Glacial Maximum. Earth Planet. Sci. Lett. 1997, 146 (3-4), 607-625.

(54) Farmer, G. L.; Barber, D.; Andrews, J. Provenance of Late Quaternary Ice-Proximal Sediments in the North Atlantic: Nd, Sr and $\mathrm{Pb}$ Isotopic Evidence. Earth Planet. Sci. Lett. 2003, 209 (1-2), 227243.

(55) Bernstein, S.; Kelemen, P. B.; Tegner, C.; Kurz, M. D.; Blusztajn, J.; Brooks, C. K. Post-Breakup Basaltic Magmatism along the East Greenland Tertiary Rifted Margin. Earth Planet. Sci. Lett. 1998, 160, 845-862.

(56) Hemond, C.; Arndt, N. T.; Lichtenstein, U.; Hofmann, A. W.; Oskarsson, N.; Steinthorsson, S. The Heterogeneous Iceland Plume: Nd-Sr-O Isotopes and Trace Element Constraints. J. Geophys. Res. 1993, 98 (B9), 15833.
(57) Mertz, D. F.; Devey, C. W.; Todt, W.; Stoffers, P.; Hofmann, A. W. Sr-Nd-Pb Isotope Evidence against Plume-Asthenosphere Mixing North of Iceland. Earth Planet. Sci. Lett. 1991, 107 (2), 243-255.

(58) Rickli, J.; Frank, M.; Baker, A. R.; Aciego, S.; de Souza, G.; Georg, R. B.; Halliday, A. N. Hafnium and Neodymium Isotopes in Surface Waters of the Eastern Atlantic Ocean: Implications for Sources and Inputs of Trace Metals to the Ocean. Geochim. Cosmochim. Acta 2010, 74 (2), 540-557.

(59) Kumar, A.; Abouchami, W.; Galer, S. J. G.; Garrison, V. H.; Williams, E.; Andreae, M. O. A Radiogenic Isotope Tracer Study of Transatlantic Dust Transport from Africa to the Caribbean. Atmos. Environ. 2014, 82, 130-143.

(60) Bozlaker, A.; Prospero, J. M.; Price, J.; Chellam, S. Linking Barbados Mineral Dust Aerosols to North African Sources Using Elemental Composition and Radiogenic $\mathrm{Sr}, \mathrm{Nd}$, and $\mathrm{Pb}$ Isotope Signatures. J. Geophys. Res. Atmos. 2018, 123 (2), 1384-1400.

(61) Grousset, F.; Biscaye, P. Tracing Dust Sources and Transport Patterns Using Sr, Nd and Pb Isotopes. Chem. Geol. 2005, 222 (3-4), 149-167.

(62) Goldstein, S. L.; O’Nions, R. K.; Hamilton, P. J. A Sm-Nd Isotopic Study of Atmospheric Dusts and Particulates from Major River Systems. Earth Planet. Sci. Lett. 1984, 70 (2), 221-236.

(63) Klein, E. M. Geochemistry of the Igneous Oceanic Crust. Treatise Geochem. 2003, 3, 433-463.

(64) Chauvel, C.; Garçon, M.; Bureau, S.; Besnault, A.; Jahn, B.; Ding, Z. Constraints from Loess on the $\mathrm{Hf}-\mathrm{Nd}$ Isotopic Composition of the Upper Continental Crust. Earth Planet. Sci. Lett. 2014, 388, $48-58$.

(65) Dammshäuser, A.; Wagener, T.; Garbe-Schönberg, D.; Croot, P. Particulate and Dissolved Aluminum and Titanium in the Upper Water Column of the Atlantic Ocean. Deep Sea Res., Part I 2013, 73, $127-139$.

(66) Downing, G. E.; Hemming, S. R. Late Glacial and Deglacial History of Ice Rafting in the Labrador Sea: A Perspective from Radiogenic Isotopes in Marine Sediments. Spec. Pap. - Geol. Soc. Am. 2012, 113-124.

(67) Kretschmer, S.; Geibert, W.; Rutgers van der Loeff, M. M.; Schnabel, C.; Xu, S.; Mollenhauer, G. Fractionation of 230Th, $231 \mathrm{~Pa}$, and 10Be Induced by Particle Size and Composition within an OpalRich Sediment of the Atlantic Southern Ocean. Geochim. Cosmochim. Acta 2011, 75 (22), 6971-6987.

(68) Von Appen, W. J.; Pickart, R. S.; Brink, K. H.; Haine, T. W. N. Water Column Structure and Statistics of Denmark Strait Overflow Water Cyclones. Deep Sea Res., Part I 2014, 84, 110-126.

(69) Haine, T. W. N. High-Frequency Fluctuations in Denmark Strait Transport. Geophys. Res. Lett. 2010, 37, L14601.

(70) Dickson, R. R.; Brown, J. The Production of North Atlantic Deep Water: Sources, Rates, and Pathways. J. Geophys. Res. 1994, 99 (C6), 12319.

(71) Rousseau, T. C. C.; Sonke, J. E.; Chmeleff, J.; van Beek, P.; Souhaut, M.; Boaventura, G.; Seyler, P.; Jeandel, C. Rapid Neodymium Release to Marine Waters from Lithogenic Sediments in the Amazon Estuary. Nat. Commun. 2015, 6 (May), 7592.

(72) Pearce, C. R.; Jones, M. T.; Oelkers, E. H.; Pradoux, C.; Jeandel, C. The Effect of Particulate Dissolution on the Neodymium (Nd) Isotope and Rare Earth Element (REE) Composition of Seawater. Earth Planet. Sci. Lett. 2013, 369-370, 138-147.

(73) Kretschmer, S.; Rutgers van der Loeff, M. M.; Masqué, P.; Geibert, W. The Distribution of $231 \mathrm{~Pa}$ and $230 \mathrm{Th}$ between Dissolved and Particulate Phases in the Western North Atlantic. Goldschmidt 2015 Abstracts 2015, 1694.

(74) Krishnaswami, S. Authigenic Transition Elements in Pacific Pelagic Clays. Geochim. Cosmochim. Acta 1976, 40 (4), 425-434.

(75) Nozaki, Y.; Alibo, D. S. Importance of Vertical Geochemical Processes in Controlling the Oceanic Profiles of Dissolved Rare Earth Elements in the Northeastern Indian Ocean. Earth Planet. Sci. Lett. 2003, 205 (3-4), 155-172. 
(76) Bacon, M. P.; Anderson, R. F. Distribution of Thorium Isotopes between Dissolved and Particulate Forms in the Deep Sea. J. Geophys. Res. 1982, 87 (C3), 2045.

(77) Grousset, F.; Biscaye, P.; Zindler, a; Prospero, J.; Chester, R. Neodymium Isotopes as Tracers in Marine Sediments and Aerosols: North Atlantic. Earth Planet. Sci. Lett. 1988, 87 (4), 367-378.

(78) Grousset, F. E.; Parra, M.; Bory, A.; Martinez, P.; Bertrand, P.; Shimmield, G.; Ellam, R. M. Saharan Wind Regimes Traced By The $\mathrm{Sr}-\mathrm{Nd}$ Isotopic Composition Of Subtropical Atlantic Sediments: Last Glacial Maximum vs Today. Quat. Sci. Rev. 1998, 17 (4-5), 395-409.

(79) Goldstein, S. L.; O’Nions, R. K. Nd and Sr Isotopic Relationships in Pelagic Clay and Ferromanganese Deposits. Nature 1981, 292, 324-327.

(80) Lacan, F. Nordic Sea and Subarctic Atlantic Water Masses Traced by Neodymium Isotopes (Masses d'eau des Mers Nordiques et de l'Atlantique Subarctique tracées par les isotopes du néodyme); PhD Thesis, 293 pp. Toulouse III University, France, 2002.

(81) Revel, M.; Sinko, J. a.; Grousset, F. E.; Biscaye, P. E. Sr and Nd Isotopes as Tracers of North Atlantic Lithic Particles: Paleoclimatic Implications. Paleoceanography 1996, 11 (1), 95.

(82) Verplanck, E. P.; Farmer, G. L.; Andrews, J.; Dunhill, G.; Millo, C. Provenance of Quaternary Glacial and Glacimarine Sediments along the Southeast Greenland Margin. Earth Planet. Sci. Lett. 2009, $286(1-2), 52-62$.

(83) Schlitzer, R. Ocean Data View; 2016. 